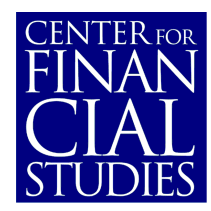

No. $2003 / 15$

\title{
Contractual Relations between European VC-Funds and Investors: The Impact of Reputation and Bargaining Power on Contractual Design
}

Daniel Schmidt, Mark Wahrenburg

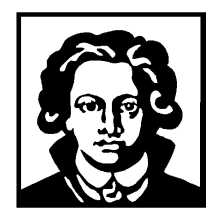




\title{
Contractual Relations between European VC-Funds and Investors: The Impact of Reputation and Bargaining Power on Contractual Design*
}

\author{
Daniel Schmidt, Mark Wahrenburg ** \\ Revised Version: March 2003
}

\begin{abstract}
The paper explores factors that influence the design of financing contracts between venture capital investors and European venture capital funds. 122 Private Placement Memoranda and 46 Partnership Agreements are investigated in respect to the use of covenant restrictions and compensation schemes. The analysis focuses on the impact of two key factors: the reputation of VC-funds and changes in the overall demand for venture capital services.

We find that established funds are more severely restricted by contractual covenants. This contradicts the conventional wisdom which assumes that established market participants care more about their reputation, have less incentive to behave opportunistically and therefore need less covenant restrictions. We also find that managers of established funds are more often obliged to invest own capital alongside with investors money. We interpret this as evidence that established funds have actually less reason to care about their reputation as compared to young funds. One reason for this surprising result could be that managers of established VC funds are older and closer to retirement and therefore put less weight on the effects of their actions on future business opportunities.

We also explore the effects of venture capital supply on contract design. Gompers and Lerner (1996) show that VC-funds in the US are able to reduce the number of restrictive covenants in years with high supply of venture capital and interpret this as a result of increased bargaining power by VC-funds. We do not find similar evidence for Europe. Instead, we find that VCfunds receive less base compensation and higher performance related compensation in years with strong capital inflows into the $\mathrm{VC}$ industry. This may be interpreted as a signal of overconfidence: Strong investor demand seems to coincide with overoptimistic expectations by fund managers which make them willing to accept higher powered incentive schemes.
\end{abstract}

\section{JEL Classification: G32}

Keywords: Venture Capital, Contracting, Limited Partnership, Funds, Principal Agent, Compensation, Covenants, Reputation, Bargaining Power

\footnotetext{
We thank EPRES Center of Private Equity Research for delivering data.

** Correspondence:

Dipl.-Kfm. Daniel Schmidt, VCM Center of Private Equity Research und Lehrstuhl für Betriebswirtschaftslehre, insb. Bankbetriebslehre, Johann Wolfgang Goethe-Universität, Mertonstr. 17, D-60054 Frankfurt/Main, Germany, Email: d.schmidt@wiwi.uni-frankfurt.de;

Prof. Dr. Mark Wahrenburg, Lehrstuhl für Betriebswirtschaftslehre, insb. Bankbetriebslehre, Johann Wolfgang Goethe-Universität, Mertonstr. 17, D-60054 Frankfurt/Main, Germany, Email: wahrenburg@wiwi.uni-frankfurt.de;
} 


\section{Introduction}

Long-term contracts that govern relationships between venture capital (VC) partnerships and investors determine all rights and obligations between the parties over the entire period of capital investment. A sophisticated contractual design may reduce principal-agent costs in the relation between investors and VC-fund-managers. Covenants that restrict the venture capitalists' scope of action and compensation terms are the key items that govern the principal agent relationship. Based on the information exchanged at an initial date the parties design a pareto-optimal long-term contract. ${ }^{1}$ The initial design of the partnership agreement (PA) is important because renegotiations are often very difficult to achieve due to the large number of involved investors.

The VC-market is characterized by large information asymmetries. ${ }^{2}$ Partnership agreements are not made public and show a high degree of dispersion. We are interested in the factors that affect contract design. In particular, we examine the effects of the reputation and bargaining power of VC-funds on the design of partnership agreements. Furthermore, we compare our results to those of the US in order to understand differences and similarities across both markets.

In the United States, the VC-industry grew dramatically during the late 1970s and early 1980s. It is today a mature and well established investment alternative. ${ }^{3}$ The Employee Retirement Income Security Act (ERISA) of 1979 was the most important factor accounting for the strong increase in capital inflows from institutional investors, especially pension funds, into the VC-sector. ${ }^{4}$ In contrast, the continental European VC-fund industry used to be a very small market segment until the mid $1990^{\text {th }}$ and often is still today believed to be underdeveloped as compared to the US market. Figure 1 shows that the volume of the European private equity market between 1995 and 2001 evolved very similar to the development of the US market between 1978 and 1984. Existing empirical VC research concentrates on the US market. The long lasting US VC-history provides a much broader data

\footnotetext{
${ }^{1}$ See Hart, O. /Holmström, B (1985), pp. 74 ff.

${ }^{2}$ See Feinendegen / Schmidt / Wahrenburg (2002), pp. 1.

${ }^{3}$ According to Fenn/Liang/Prowse (1997), pp. 10 ff. and Yli-Renko/Hay (1999), pp. 25 ff. the Anglo-Saxon PEmarkets are also more established than the markets of continental Europe. Mainly the Anglo-Saxon buy-out market has a longer tradition than its Continental-European counterpart. About the history of private venture capital partnerships see Owen/Gardner/Bunder (1986), pp.77.

${ }^{4}$ See Gompers/Lerner (1996), pp. 466.
} 
base for research. ${ }^{5}$ Very little empirical insight into the European market segment exists up to date. $^{6}$

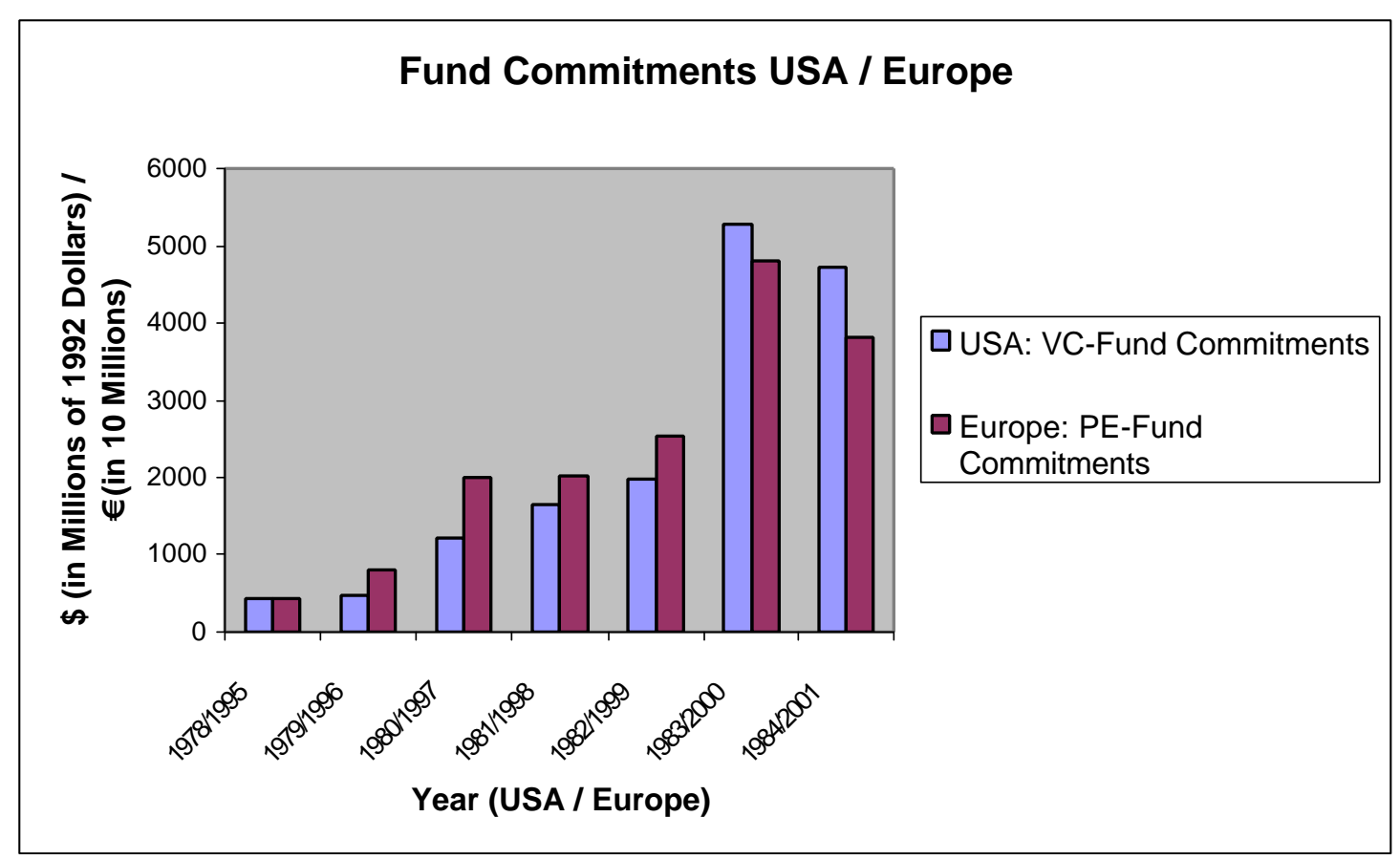

Figure 1 - Funds committed to independent US venture capital partnerships and to European Private Equity (PE) Funds. The US and the European data are obtained from the Venture Economics database and the EVCA-Yearbook 2001, respectably. No data for European VCfund commitments are available for the year preceding 1998. Therefore data of PE-fund commitments are used for comparison.

In this study, we analyse 122 Private Placement Memoranda (PPM) and 46 partnership agreements of European VC-funds, which were raised between 1996 and the end of 2001. The key elements of partnership agreements analysed in this article are the compensation terms, the general partners own capital contribution to the fund, and the covenants that restrict the venture capitalists' actions. ${ }^{7}$ The size and quality of the analyzed dataset is unique and allows a highly representative analysis of contractual relations for the European VC-market. Given the similar growth pattern of the US VC-industry in the 1980s and the European VC-industry in the ending 1990s, results of this study seem to be comparable to two studies conducted by Gompers and Lerner in 1996 and 1999, which analyse US VC-partnership agreements for the time span between 1979 and 1992.

We find that established funds have more contractual covenants than young debut funds with no established reputation. This contradicts the conventional argument which states that

\footnotetext{
${ }^{5}$ See Barry (1994), pp.13.

${ }^{6}$ See Bascha/Walz (2001), pp. 1.

${ }^{7}$ See Sahlmann (1990), pp. 489 ff. and Gompers/Lerner (1996), pp. 464.
} 
established market funds care more about their reputation, have their incentives better aligned with investors and therefore there is less need to use restrictive covenants. We also find that managers of established funds are more often obliged to invest own capital alongside with investors money. We interpret this as evidence that established funds have actually less reason to care about their reputation as compared to debut funds. Young fund managers may be better aligned with investors' interests because only a good track record enables them to initiate profitable future fund raising campaigns. In contrast, managers of established VC funds are older and closer to retirement and therefore put less weight on the effects of their actions on future business opportunities.

Contract design may also be affected by bargaining power effects. Gompers and Lerner (1996) show that VC-funds in the US are able to reduce the number of restrictive covenants in years with high supply of venture capital and interpret this as a result of increased bargaining power by VC-funds. We do not find similar evidence for Europe. Instead, we find that VCfunds receive less base compensation and higher performance related compensation in years with strong capital inflows into the VC industry. We interpret this as an indication that fund managers may have been the victim of overconfidence.

The paper is organized as follows: Section II outlines the principal agent problems between investors and venture capitalists and the importance of contractual arrangements. The section also describes the contractual items used in this study. Section III derives testable hypothesis based on existing theoretical models. Section IV summarizes related empirical evidence for the US. Section V describes in detail our data sample and provides summary statistics. Section VI presents the empirical results of the descriptive and uni-/multivariate analysis for Europe. Section VII concludes and gives an outlook on future research.

\section{Contractual relations between VC limited partnerships and investors}

\section{a. Conflicts of interest}

Barry (1994) characterizes the VC process as a multiple-agent relationship. Agency problems arise at the interaction between the venture capitalist and both the investors and the entrepreneurs. ${ }^{8}$ The present study concentrates on the first step and analyses the relation between investors and venture capitalist.

\footnotetext{
${ }^{8}$ See Barry (1994), pp.12 f.
} 
The literature on agency problems in VC markets covers mainly the relationship between VC-firm and portfolio-company. This is the typical principal-agent framework where the entrepreneur is the agent and the venture capitalist is the principal. Less analysed is the additional relationship between the outside investors and the VC-fund. Sahlmann (1990) describes both levels of asymmetric information in a VC limited partnership. He gives an overview of VC-funding and describes potential conflicts between venture capitalists and their investors. Sahlmann suggests the solution for that principal-agent problem in an appropriate design of partnership agreements. Barry (1994) summarises former studies of VC funding. Moreover, he analyses new directions of potential research. He suggests the progress in research of "the contracting technology that permits venture capitalists to manage their dual roles as agents with respect to their limited partners-investors and as principals with respect to entrepreneurs in their portfolio firms." ${ }^{9}$ According to Barry, the same contractual mechanisms that are used to settle the relationships to their portfolio companies are often used to adjust investors' concerns. He points out how difficult it is to develop empirical evidence on VC. Data on VC investments are always private. ${ }^{10}$ Analysing the German VC market Zemke (1995) bases his studies about the solution of principal agent problems on empirical evidence developed from the data of 40 questionnaires. While he was doing a more general study he was even addressing contractual designs. Empirical papers by Gompers and Lerner (1996, 1999 und 2001) analyse the structure of partnership agreements including compensation terms and the use of covenants. They develop hypotheses about the relationship between certain economical aspects and both the compensation of venture capitalists and the existence of covenants. Their analyses refer exclusively to US VC partnerships. ${ }^{11}$

The investment in VC-funds is associated with a high degree of information asymmetry. Monitoring the prospects and, furthermore, understanding the business of each individual investment done by the fund is extraordinary difficult for single investors. The venture capitalist has many opportunities to behave opportunistic and to take advantage of the delegated power. These potential conflicts have to be addressed in the partnership agreements. $^{12}$

\footnotetext{
${ }^{9}$ See Barry (1994), pp. 13.

${ }^{10}$ See Barry (1994), pp. 13. Fenn, G. W./ Liang, N./ Prowse, (1996), pp. 7.

${ }^{11}$ See Tykvová, T. (2000), pp. 3 f. and Triantis, G. (2001).

${ }^{12}$ See Sahlmann (1990), pp.493 f.
} 
Grossman and Hart (1993) suppose risk sharing between the principal and the agent as a general way of reducing agency problems. ${ }^{13}$ In accordance to the findings developed in the literature of agency theory ${ }^{14}$ Spremann (1988) and (1990) identifies three contractual ways of arranging compensation terms in order to reduce agency problems: First, the level of performance related compensation of the funds' manager gives incentives to increase the capital gains of the fund. The relative level of variable to fix compensation is decisive. The complete efficiency of this incentive scheme, however, is based on the assumption, that a changing effort level of the agent can only induce higher capital gains and no capital loss. This assumption is not met in the case of VC investing. Second, the actions of the venture capitalist may be adjusted by compensating him for capital gains, but punishing him for capital loss. This effect can be achieved either by monetary or reputational gains and casualties. ${ }^{15}$ Third, an obligation to compensate the capital loss with its own liquidity gives incentives to reduce opportunistic behaviour. However, this kind of contractual arrangement is not usual in the VC-industry.

Besides these monetary incentives, contractual investment principles in form of covenants may prevent the venture capitalist from engaging in actions that are against the investors' interest.

\section{b. The VC partnership agreements}

The principal-agent relationships between investors (principal) and VC fund (agent) are governed by the partnership agreements and partly by the Private Placement Memoranda. The partnership agreements contain all relevant details, which determine the venture capitalists' and the investors' obligations. Private Placement Memoranda are usually used as marketing instruments representing only the key elements of the contractual relations between VC-fund and investors. The following key elements of partnership agreements represent the practical conversion of the mentioned theoretical aspects of financial contracting.

\footnotetext{
${ }^{13}$ See Grossman/Hart (1983), pp.7.

${ }^{14}$ See Alchian/Demsetz (1972); Ross (1973); Stiglitz (1974); Mirrlees (1975); Jensen/Meckling (1976); Grossman/Hart (1983); Rees (1985).

${ }^{15}$ In the case of venture capital the managing directors are tied to monetary loss of the fund, if they made a capital contribution to the fund (own partnership shares). Our empirical results, however, disclose no correlation between the existence of a capital contribution done by the managing directors and their reputation. Therefore a substitution of one incentive given by a high reputation for another incentive (capital contribution) cannot be claimed. See theoretical discussion also in Hart, O. /Holmström, B (1985), pp. 79 f.
} 


\section{i. Compensation terms}

The VC-firm receives two kinds of compensation for managing the investments in each limited partnership: the fixed component is the "management fee", the performance related component is the "carried interest".

The management fee is, in general, expressed as a percentage on the committed capital and paid annually. Often the fee is tapered after the commitment period. This reflects the fact that less time has to be spent in managing activities, if the investments are mature and partly realized. Tapering the management fee is effected by either reducing the accounting basis on which the rate is applied - for example by replacing the committed capital by the real capital under management - or by reducing the percentage rate, which has to be paid for compensation. A tapered fee corresponds to the real purpose of the management fee to cover the costs of running and administering the fund.

The second source of compensation, the carried interest, entitles the venture capitalists to a certain share of the capital gains of the fund. ${ }^{16}$ This incentive compensation corresponds to the first theoretical aspect of financial contracting mentioned by Spremann. The carried interest is only paid, if the investor has received back at least hundred per cent of his invested capital. Some partnerships contain a hurdle rate, which represents a preferred annually interest payment to the investor. The hurdle rate, however, is not a guaranteed interest payment to the investor. The existence of a hurdle rate reduces the VC-managers' value of his carry option.

Arrangements which obligate the managing directors to make a capital contribution to the fund increase the incentives to achieve high performance. While they invest their own capital in the vehicle the responsible managers also share a capital loss of the fund. This contractual obligation corresponds to Spremanns' second theoretical proposal of reducing agency problems.

\section{ii. Covenants}

Besides incentives that are provides by compensation terms, certain contractual restrictions regulate the actions of the managing directors. The covenants may prevent the funds' managers from opportunistic behaviour and from acting in a selfish way. The conceptual framework commonly used in incomplete contract literature usually assumes that contractual incompleteness is due to the transaction costs of describing or foreseeing future

\footnotetext{
${ }^{16}$ See Brooks (1999), pp. 109 f., Sahlmann (1990), pp.491, Initiative Europe (2001), pp.10 ff.
} 
states of nature in advance. According to the legal scholars of "incomplete contracting" the implementation of suitable covenants should fill the gaps in incomplete contracts. ${ }^{17} \mathrm{~A}$ better specification of the venture capitalists' obligations reduces future opportunities of opportunistic behaviour. Gompers/Lerner (1996) identified 14 covenants of US VCpartnership agreements. In accordance to this study, we explored for a better comparison of the results the 14 most relevant and frequent covenants of European partnership agreements. The analysed covenants regulate relevant aspects of the principal agent relationship and safeguard the investors' interests. We divided the analysed covenants into three classes: Class one covenants regulate the overall funds' management. Covenants of class two and of class three restrict the activities of the managing directors and the types of investments, respectively. ${ }^{18}$

\section{Hypothesis about the determinants of contractual design}

\section{a. Reputation as a driver of contractual design}

Raising funds is a function of the venture capitalists' ability to convince potential investors of their management quality. This means, only high performance venture capitalists are able to raise follow-on-funds and, while working trustworthy, to develop high reputation. Tradelis (1997) developed a reputation model in which a firms' only asset is its name. This comes close to the situation in the VC business where a respected name is the basis of high reputation. Spremann (1988) discusses reputation in general as an incentive to continue high quality management and not to engage in opportunistic behaviour. Within the principal agent relationship reputation can be seen as a security given by the agent to the principal. The value of that security is developed, because misbehaviour or actions against the interests of the principal may reduce the agents' reputational capital. As a result, opportunities of future fund raisings would decline. ${ }^{19}$ The potential opportunity of losing reputation may be seen as an extraordinary intangible contract between the investor and the venture capitalist. ${ }^{20}$ This additional security given by high reputation may have effects on the compensation terms and the need for covenants.

\footnotetext{
${ }^{17}$ See Ayres, I. / Gertner, R. (1992).

${ }^{18}$ See Wahrenburg/ Feinendegen / Schmidt (2002) give a detailed overview of all covenant classes and their effects in a principal agent relationship. The appendix gives a quality description of the analysed covenants.

${ }^{19}$ See also the incentive schemes of section 2.a: The loss of reputation can be seen as a punishment for opportunistic behavior.

${ }^{20}$ See Spremann (1988), pp. 619.
} 
Leaving out important covenants that regulate the relation between investors and the venture capitalists means less specified obligations for future states. These incomplete contracts open opportunities of acting in an opportunistic way, because future contract renegotiations are unusual and mostly not possible. Inherent incentives given by the risk of loosing reputation may adjust those less specified contractual relations. The costly need to implement covenants may be reduced. On the contrary, young venture capitalists without reputational capital are confronted with an increased need to specify their future obligations. They have no inherent incentives given by the existence of reputation which fill the gaps of incomplete contracts without the needed restrictions. According to that common theoretical approach we develop the hypothesis that fund managers with high reputation integrate fewer covenants that are costly to implement and to monitor.

Venture capitalists with high reputation will charge that additional security. Gompers and Lerner (1999) introduce two models which could explain the variation in compensation. ${ }^{21}$ The signalling model predicts higher fixed fees for older and larger venture capital organizations that demand insurance. They charge that additional security given by a high reputation. They demand for higher fixed fees. Non-debut funds with established reputation, therefore, have relatively lower powered monetary incentive schemes than first time funds. Here, incentives are given by a potential loss of their reputation. On the contrary, the learning model predicts first time fund managers to work harder anyway to gain reputation. Highly incentive compensation is not necessary. This model predicts that young managers charge higher fixed fees in relation to performance related fees. Therefore, debut funds have less monetary incentives.

\section{b. Bargaining power as a driver of contractual design}

This hypothesis contends that the relative supply and demand situation in the VC-market determines the bargaining power of the managers in times of fund raising. Since the partnership agreements are usually not renegotiated, this is not a repeated bargaining environment. $^{22}$ The fund managers' bargaining power at an initial date affects the contractual design and, therefore, all future options. According to a certain supply/demand situation the equilibrium price adjustment takes place. This happens invisible through the insertion or deletion of covenants and visible through explicit monetary compensation. Less contractual

\footnotetext{
${ }^{21}$ Complete description and derivation of the learning and signalling model in Gompers/Lerner (1999), pp. $7 \mathrm{ff}$. and Appendix A and B.

${ }^{22}$ For a model of repeated bargaining see Eberwein (2000).
} 
restrictiveness and higher fixed or higher performance related compensation represent both different kinds of non-monetary and monetary charges, respectively, the investor has to pay. It is less likely to attract the investors' attention by varying less visible contractual elements, e.g. the number of included covenants. ${ }^{23}$ Consequently these less visible contractual elements are often subject to high variations, in contrast to highly standardized well known contract elements.

The equilibrium price of venture capital services increases in times with high relative demand for VC-services. We assume that the fund managers use their bargaining power to lower their bonding costs. Fewer covenants which restrict the managers' future options may be included. Though real life VC long term partnership agreements do not completely conform the predictions of complete contracting, contracts in times with high demand for VCservices may be less sophisticated.

Next to declining bonding costs, an increase of the equilibrium price for VC-services can effect higher 'monetary' compensations. We assume that venture capitalists in times with relatively high demand for their services use that negotiating power. They may try to save that temporary advantage for the whole funds' lifetime by demanding higher fixed fees. Just the fixed management fee is that part of the compensation which is guaranteed and calculable over the next years. Assuming increasing fixed payments, the performance sensitivity of compensation and, therefore, the degree of management incentives are decreasing.

\section{Related literature - empirical evidence for the US}

Gompers / Lerner (1999) and (1996) analyse the contractual relations between investors and US venture capital funds. They also examine the use of covenants and compensation terms as contractual arrangements to reduce agency problems. Gompers and Lerner (1999) find empirical evidence that reputation is an important factor determining compensation terms. In the US, fund managers with high reputation charge lower fixed fees. The sensitivity to performance is higher. These findings are consistent with the learning model. They found no significant effect of reputation on the use of covenants.

On the other hand, a relatively higher demand for VC-services leads to a declining number of included covenants. The number of covenants is reduced in growth years. US venture capitalists use their bargaining power to lower their bonding costs. Since there is no

\footnotetext{
${ }^{23}$ According to Gompers/Lerner (1996), pp. 472.
} 
effect of higher bargaining power on the monetary "compensation" like management fee or carry, conditions of new demand/supply situations are exclusively adjusted by varying invisible elements. ${ }^{24}$ Contractual relations become incomplete. A new equilibrium price of VC-services is not adjusted by the price mechanism through varying monetary charges. This indicates inefficient contracting. Obligations to make a capital contribution and the implementation of hurdle rates were not analysed by Gompers and Lerner. No value of the carry option was calculated.

\section{The data sample}

A dataset comprising of 122 private placement memoranda and 46 partnership agreements of European VC-funds is used for this study. Data was collected from the archive of one of the oldest and largest VC fund of fund firms in Europe. We restricted the analysis to independent private limited partnerships, which engage exclusively in VC investment and are located in a European country. We did not include PPM's and PA's which had other investment types stated in their prospectus, such as LBO's, MBO's, or turnarounds. If the fund was managed from different offices in Europe, we use the country of the main office as the funds' origin.

Placement memoranda and partnership agreements are confidential data and not publicly available. Therefore, a complete survey of all European funds is not possible. The sample is taken from the original deal flow which is not subject to a selection bias. We assessed the completeness and representativeness of the sample by comparing it with the market data published by the European venture capital association (EVCA). Table 1 shows the samples' summary statistics. The level of representativeness is examined in the first row. The complete sample represents 35 per cent of the overall European market of independent VC-funds. ${ }^{25}$ Besides statements about the overall market, we developed all measures for the three countries with the highest aggregated sample volume of funds raised. The survey of German VC funds is almost complete. The level of representativeness of UK-based partnerships is also above the mean. Furthermore, the sample is well balanced concerning characteristics like the time in business, the experience, the investment stage, and sector. The sample size until the year 1997 is quite small. This concerns to the fact, that in the UK, which is the country

\footnotetext{
${ }^{24}$ Gompers /Lerner (1999), pp. 23 ff. and Gompers / Lerner (1996), pp. 490.

25 The European venture capital association (EVCA) is only recording the volume of independent VC-funds raised since the year 1998. No statements are made about the number of venture capital firms on the market. Therefore the degree of representativeness is measured on basis of the samples and the overall markets funds' volume of the years 1998, 1999, and 2000. No distortion should be assumed, because the development of the VC-market corresponds to the development of the deal flow.
} 
with the longest history of private equity financing, mainly buy out funds emerged in the 80ties and early 90ties. The establishment of new market segments like the EASDAQ in Brussels and other new markets in continental Europe between the year 1996 and 1997 were basically the reason for a growing VC-industry.

\begin{tabular}{|c|c|c|c|c|}
\hline & Total sample & Germany & UK & France \\
\hline \multicolumn{5}{|c|}{ Representativeness of sample } \\
\hline Funds volume & $35 \%$ & $95,30 \%$ & $37,10 \%$ & $27,55 \%$ \\
\hline \multicolumn{5}{|c|}{ Funds size [Mio $€$ ] } \\
\hline Mean & 130,8 & 116 & 143 & 95 \\
\hline Median & 75,6 & 50 & 120 & 91 \\
\hline Std. deviation & 227 & 278 & 96 & 60 \\
\hline \multicolumn{5}{|c|}{ Time in Business [years] } \\
\hline Mean & 4 & 3,3 & 4,8 & 5,5 \\
\hline Median & 2 & 1 & 2,5 & 4 \\
\hline Std. deviation & 5,16 & 4,8 & 6 & 4,9 \\
\hline \multicolumn{5}{|c|}{ Investment stage [percentage on survey] } \\
\hline Early & $58,20 \%$ & $57,20 \%$ & $50,00 \%$ & $76,90 \%$ \\
\hline Balanced & $30,40 \%$ & $33,30 \%$ & $35,70 \%$ & $15,40 \%$ \\
\hline Later & $11,40 \%$ & $9,50 \%$ & $14,30 \%$ & $7,70 \%$ \\
\hline \multicolumn{5}{|c|}{ Investment sector [percentage on survey] } \\
\hline High-tech & $91,80 \%$ & $95,00 \%$ & $96,00 \%$ & $100 \%$ \\
\hline Non-high-tech & $8,20 \%$ & $5,00 \%$ & $4,00 \%$ & \\
\hline \multicolumn{5}{|c|}{ Reputation [percentage on survey] } \\
\hline Debut fund & $47,15 \%$ & $59,52 \%$ & $42,86 \%$ & $23,08 \%$ \\
\hline Non-debut fund & $52,85 \%$ & $40,48 \%$ & $57,14 \%$ & $76,92 \%$ \\
\hline \multicolumn{5}{|l|}{ Date } \\
\hline 1996 & $2,50 \%$ & $5 \%$ & & \\
\hline 1997 & $2,50 \%$ & & & $8 \%$ \\
\hline 1998 & $9 \%$ & $12 \%$ & $8 \%$ & $15 \%$ \\
\hline 1999 & $18 \%$ & $24 \%$ & $25 \%$ & $15 \%$ \\
\hline 2000 & $37 \%$ & $35 \%$ & $35 \%$ & $54 \%$ \\
\hline 2001 & $31 \%$ & $24 \%$ & $32 \%$ & $8 \%$ \\
\hline \multicolumn{5}{|c|}{$\begin{array}{l}\text { Notes: This sample descriptive refers to the complete dataset of } 122 \text { European VC-Funds. Funds originated in the } \\
\text { following countries were included (number of included funds): Germany (43), UK (29), Switzerland (5), } \\
\text { Netherlands (5), Norway (3), France (13), Sweden (4), Italy (2), Ireland (3), Belgium (4), Iceland (1), Spain (1), } \\
\text { Luxemburg (1), Denmark (2), Finland (1), Pan-European (5). The representativeness of the sample is measured as } \\
\text { the ratio of the aggregated funds volume of the sample partnerships (total or each regional segment) and the total } \\
\text { volume of the VC-market (total or the regional segment). For calculations in the last three columns, the data of } \\
\text { every country are used as completely separate datasets. }\end{array}$} \\
\hline
\end{tabular}

We collected the relevant data on compensation terms (Management Fee, Carried Interest, Hurdle Rate) from the PPMs. These offering memoranda are used as marketing instruments and describe all details on the VC-firm, the funds' manager, the investment strategy and the investment conditions. Using the PAs we generated a separate dataset for the analysis of the included covenants and capital contributions of the funds' manager. The PAs contain all relevant data, including data about the rights and obligations of the managing directors and the limited partners. For every PA the corresponding PPM was available. So we 
could verify all compensation data with those we have collected from the PPMs. All currencies were converted to Euro.

\section{Empirical results for Europe}

In this section, we examine the factors that affect contract design. We use several proxies of reputation and bargaining power and employ univariate as well as multivariate empirical tests.

\section{a. Descriptive statistics}

The relations between the investors and the venture capitalists are basically determined by the mentioned contractual arrangements. These are both the included covenants and the sensitivity of compensation determined by the level of the management fee over the funds' life, the carried interest, the hurdle rate, and the capital contribution. The agreements are quite heterogenous and observing these variables are connected with different efforts. The management fee, the carried interest, and the hurdle rate are represented in the easy readable and understandable private placement memoranda. The obligated degree of capital contribution and the included covenants are difficult to observe from the partnership agreements.

Easy visible factors are highly standardized. Figure 2 presents the distribution of the management fee which has to be paid in the first years after closing (this is constant for the years of the commitment period). It shows, that 60 (20) per cent of the venture capitalists charge 2,5 (2) per cent p.a. of committed capital as a fixed fee.

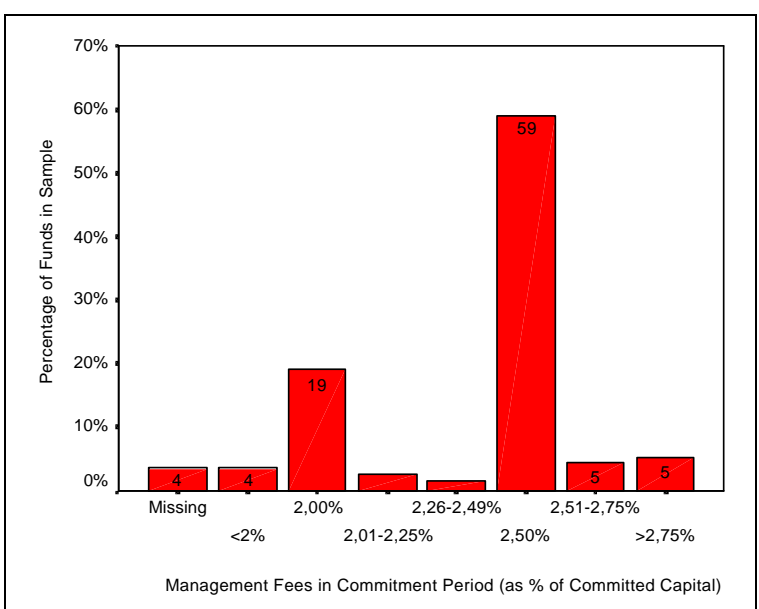

Figure 2: Management Fee

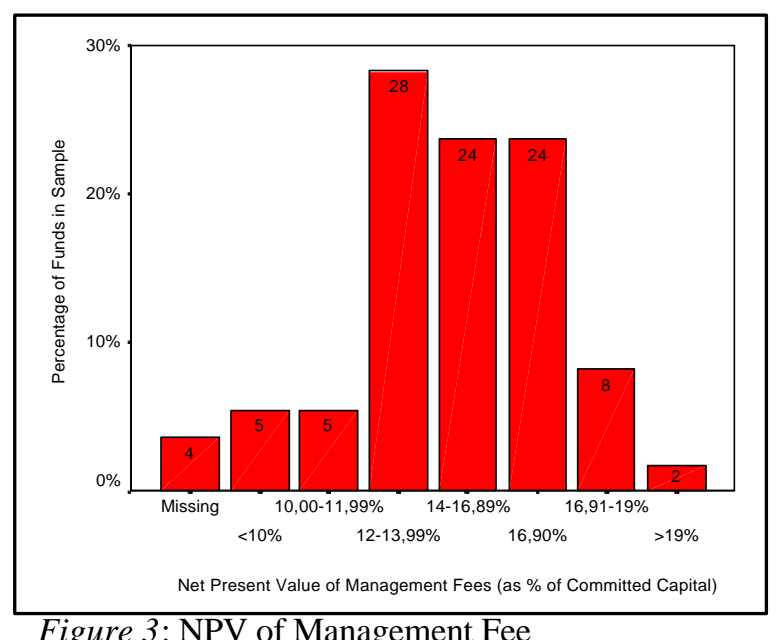

Figure 3: NPV of Management Fee

Coping the assumptions of the bargaining power hypothesis that fund managers with high bargaining power are induced to increase their fixed compensation over the whole funds' 
life, we base our analyses on the net present value of management fee paid over the whole funds' life. ${ }^{26}$ The present value of the management fee paid over the funds' life is the real charge that the investor has to pay for the funds' management. Figure 3 presents the distribution of the net present value of the management fee. It shows that its degree differs much more between the funds than the management fee paid in the first years.

While examining the distribution of the carried interest we show that about 90 per cent of the VC-firms are allocated to 20 per cent of the profits (Figure 4). This exceeds the level of standardization, which was found for US VC-funds. Gompers/Lerner (1999) found only in 81 per cent of the US-sample a carried interest between 20 and 21 per cent of the capital gains. The distribution of the hurdle rates, as preferred returns given to the investor, is shown in figure 5. Nearly $50 \%$ of the funds do not have any hurdle rate. The variation is much higher as that of the carried interest.

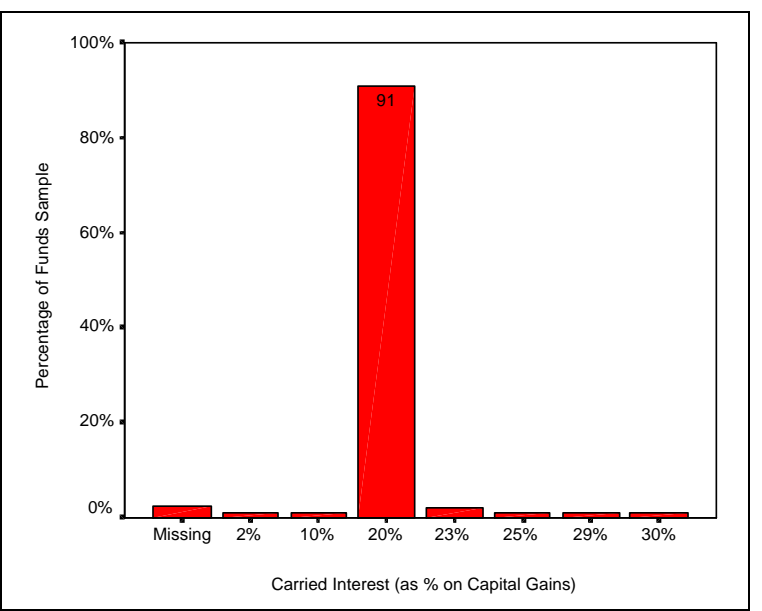

Figure 4: Carried Interest

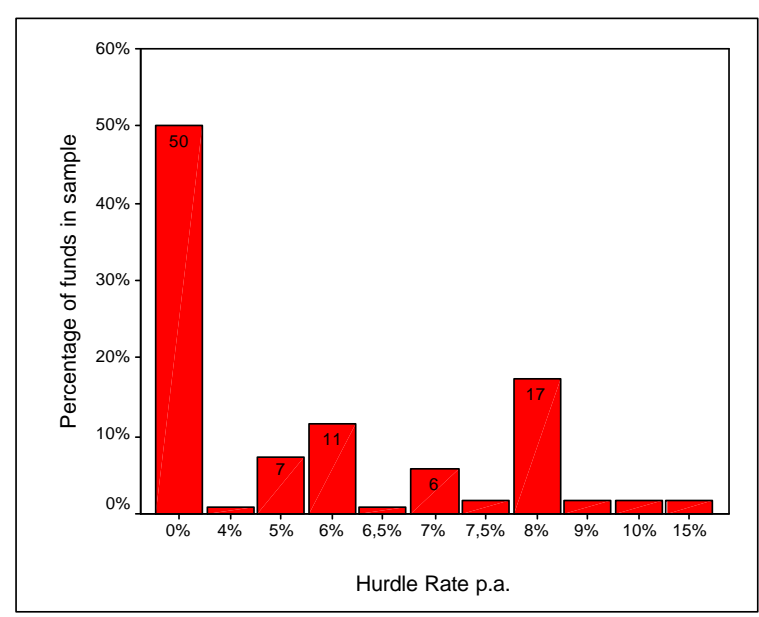

Figure 5: Hurdle Rate

In general, the venture capitalists' equity participation has the character of a call option that entitles the venture capitalists to a certain share of the increase in value of the underlying fund. The exercise price corresponds to the cost basis of the fund. The hurdle rate has to be taken into account. The funds' life equals the life of the option. ${ }^{27}$ Based on a Binomial model, we calculated the option value under consideration of a changing participation on capital

\footnotetext{
26 For calculating the NPV of the management fee we made the following assumptions: Following Gompers/Lerner (1999), we discounted the annually management fee (as a particular percentage on committed capital) with a rate of $10 \%$. If the base used to calculate the fee varies over fund life and if its level is becoming uncertain (e.g., the capital under management), we discounted the corresponding fee with an increased rate of $20 \%$. Despite that the individual funds' life time is usually stated in the PPMs', we calculated the NPV of the management fee over a standardized time period of ten years. This concerns to the fact that usually a life time extension is possible. An exact time period, during which the investor has to pay the fee, is not predictable. An assumed life time of 10 years excludes incorrect changes of the calculated level of the NPV of the management fee as a result of different inexact statements that are made in advance. This calculation procedure is the same done by Gompers and Lerner. For more information see Gompers/Lerner (1999), Appendix D.

${ }^{27}$ See examples in Sahlmann (1990), pp. 496.
} 
gains (carry) and changing hurdle rates. This numerical analysis suggests that the ex ante mean value of the carry option is about 15.30 (median: $15.22 \%$ ) per cent of the total invested fund capital. ${ }^{28}$ There is a $92 \%$ concentration of the carry option value at 15.22 per cent. This high standardization is reasoned by the ignorable effect of the relatively small hurdle rates on the option value. Its value is exclusively determined by the changing performance participation. In Europe, variations of incentive compensation, therefore, mainly base on the varying degree of fixed payments in relation to both the highly standardized performance related payments and the option value of the carried interest.

Following Spremanns' agency theoretical explanations a purely participation in capital gains, like the carried interest, has only limited effect to increase the venture capitalists' incentives to act in accordance with the investors interests. A capital contribution of the managing directors ties their monetary interests directly to the investors' interests. An additional, but less visible instrument of increasing the incentives, therefore, is the capital contribution done by the managing directors. Obligatory arrangements are components of the partnership agreements. Figure 6 presents the distribution of the obligated capital contributions. About 38 per cent of the samples' venture capitalists make no capital contribution and fail to add this relevant incentive scheme.

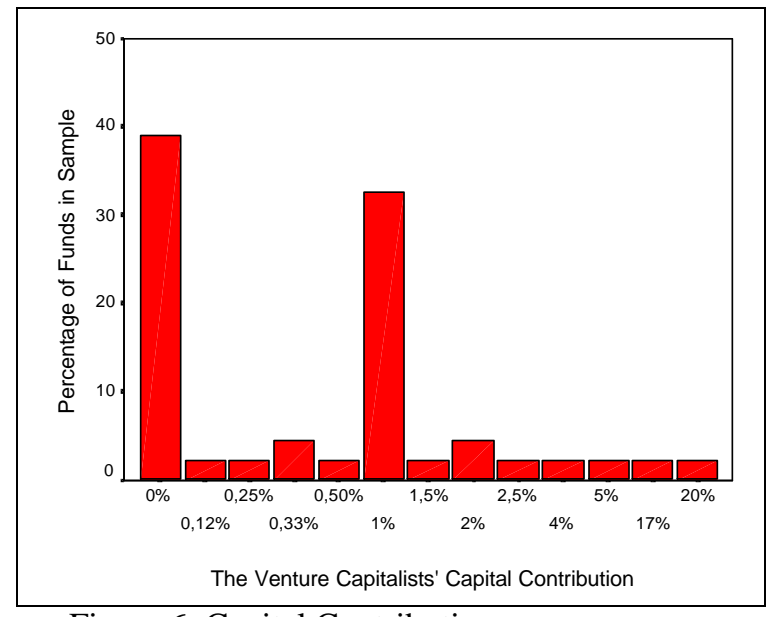

Figure 6: Capital Contribution

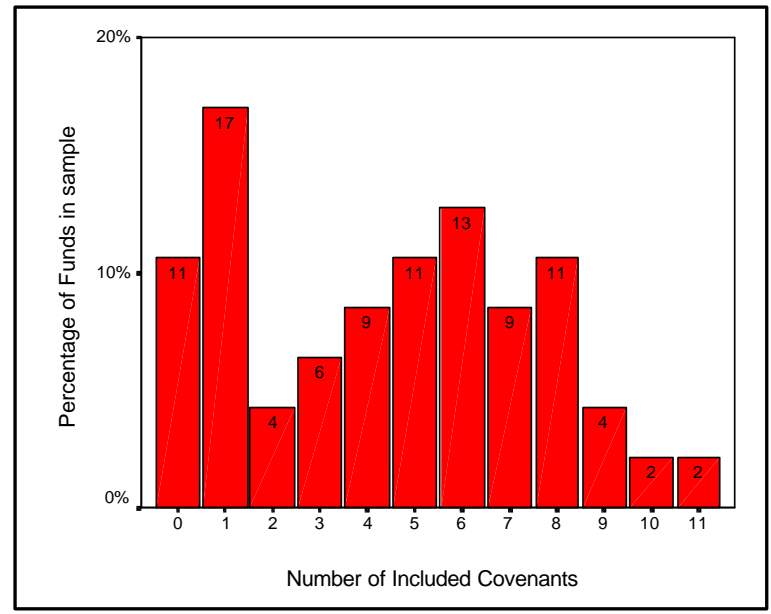

Figure 7: Number of Covenants

\footnotetext{
${ }^{28}$ We based these calculations on similar assumptions made by Sahlmann (1990), pp.496 ff. Using the BlackScholes model, the options' value is a function of volatility, the current market value of the funds' assets, the risk free rate, the profit participation (in\%), the time to maturity, the strike price, and the hurdle rate. We assumed that the current market value of the fund equals the total original capital of the fund (the funds' costs). We set the median time to maturity of the samples' funds (10 years) as the options lifetime. According to Sahlmann (1990), we assumed a risk free rate of $10 \%$ and a volatility of $50 \%$. The level of profit participation equals the individual funds' carried interest arrangements. The strike price is set to be $100 \%$. The results without consideration of a hurdle rate are consistent with those of Sahlmann (1990). Due to the fact that the hurdle rate is an annually preferred return which is paid on capital that is drawn down deal by deal, exact determinations of the real option values are not possible. The calculated option values are only approaching the real values.
} 
Covenants regulating the venture capitalists' actions are also difficult to observe, but substantial for the relationship between the involved parties. Feinendegen/ Schmidt/ Wahrenburg (2002) summarize detailed representation and frequencies of the fourteen analysed covenant classes. Figure 7 presents the distribution of the overall number of included covenants, which will be, following for better comparisons the procedure of Gompers/Lerner (1996), the basis of the regression analysis.

The descriptive statistics are summarized in table 2 .

\begin{tabular}{|c|c|c|c|c|c|c|c|}
\hline & Obs. & Min. & Max & Mean & Median & St. Dev. & Confidence level (95\%) for mean \\
\hline $\begin{array}{l}\text { Management } \\
\text { Fee }\end{array}$ & 119 & $\begin{array}{c}0,4 \% \\
\text { p.a. }\end{array}$ & $\begin{array}{c}4,0 \% \\
\text { p.a. }\end{array}$ & $\begin{array}{c}2,43 \% \\
\text { p.a. }\end{array}$ & $\begin{array}{c}2,50 \% \\
\text { p.a. }\end{array}$ & 0,00448 & $0,008 \%$ \\
\hline $\begin{array}{l}\text { PV of } \\
\text { management } \\
\text { Fee }\end{array}$ & 119 & $2,85 \%$ & $24,23 \%$ & $15,09 \%$ & $15,29 \%$ & 0,0300 & $0,54 \%$ \\
\hline $\begin{array}{l}\text { Carried } \\
\text { Interest }\end{array}$ & 120 & $2,00 \%$ & $30,00 \%$ & $20,10 \%$ & $20,00 \%$ & 0,0242 & $0,44 \%$ \\
\hline $\begin{array}{l}\text { Option Value } \\
\text { of Carried } \\
\text { Interest }\end{array}$ & 120 & $1,522 \%$ & $22,83 \%$ & $15,3 \%$ & $15,22 \%$ & 0,0183 & $0,332 \%$ \\
\hline Hurdle Rate & 122 & $0 \%$ & $\begin{array}{l}15 \% \\
\text { p.a. }\end{array}$ & $\begin{array}{c}3,6 \% \\
\text { p.a. }\end{array}$ & $2 \%$ p.a. & 0,0387 & $0,69 \%$ \\
\hline $\begin{array}{l}\text { Capital } \\
\text { contribution }\end{array}$ & 46 & $0 \%$ & $20 \%$ & $1,53 \%$ & $0,75 \%$ & 0,0381 & $1,1 \%$ \\
\hline Covenants & 46 & 0 & 11 & 4,45 & 5,00 & 3,10 & 0,92 \\
\hline $\begin{array}{l}\text { Notes: The co } \\
\text { Private placem } \\
\text { Some data con } \\
\text { were sorted ou } \\
\text { the partnership }\end{array}$ & $\begin{array}{l}\text { lete } d \\
\text { mems } \\
\text { aning } t \\
\text { nd the } \\
\text { reeme }\end{array}$ & $\begin{array}{l}\text { ataset cont } \\
\text { oranda cont } \\
\text { he Manage } \\
\text { dataset red } \\
\text { nts. }\end{array}$ & $\begin{array}{l}\text { ains inform } \\
\text { tains inform } \\
\text { ment Fee a } \\
\text { uced. Infor }\end{array}$ & $\begin{array}{l}\text { tion of } 12 \\
\text { tion about } \\
d \text { the Carı } \\
\text { ation abou }\end{array}$ & $\begin{array}{l}\text { private } p \\
\text { he Mana } \\
\text { d Interes } \\
\text { the capit }\end{array}$ & $\begin{array}{l}\text { cement me } \\
\text { ment Fee, } \\
\text { were missi } \\
\text { contributic }\end{array}$ & $\begin{array}{l}\text { randa and } 46 \text { partnership agreements. } \\
\text { Carried Interest and the Hurdle Rates. } \\
\text { For analysis the corresponding PPMs } \\
\text { and the covenants were components of }\end{array}$ \\
\hline
\end{tabular}

\section{b. Univariate comparisons}

We made univariate comparisons for that kind of contractual components, which are varying among the sample funds. The carried interest is highly standardized and, therefore, not analysed for variation in dependence of the mentioned determinants. Due to the highly standardized carried interest, incentive schemes are actually characterized and their quality is determined by the amount of capital contribution and by the ratio of performance related to fixed compensation. Furthermore contractual gaps should be closed by the implementation of covenants.

Testing the reputation hypothesis we used the differentiation debut fund manager or nondebut fund manager as the proxy for the venture capitalists' reputation. Only high performance fund managers who developed reputation by high-performing first funds are able to raise a follow on fund. First time fund managers without track record have no reputational 
capital. ${ }^{29}$ Sometimes, the VC-firms' age or time in business is used as a proxy for its reputation. In the literature this measure is developed on the assumption that VC-firms, which are able to stay a long time in business, are high quality and well positioned. Low-quality venture capitalists should be unable to raise new funds and, therefore, to stay in business over a longer period of time. ${ }^{30}$ As control variables we integrated also venture capitalists' age and the fund size. Nevertheless, we assume that the differentiation between first time fund managers and managers who have raised at least one fund before is a stronger proxy for reputation. The age of a venture capital firm and their actual fund size can be influenced by lots of other factors regardless of their reputation, e.g. an initial capital commitment by a captive sponsor to help the funds' market positioning even if it is the first fund of an unknown fund manager. ${ }^{31}$

Testing the bargaining power hypothesis we used the relative growth of the venture capital pool as the proxy for the supply/demand situation and, therefore, the managers' bargaining power. The bargaining power of the venture capitalists is rising, when the demand for $\mathrm{VC}$-services is increasing relative to a fixed number of $\mathrm{VC}$ - firms. We assume a low elasticity of new venture services (fixed number of VC-services within a short time horizon) to increasing inflows. Therefore, bargaining power can be measured by the ratio of capital inflow and the existing venture pool. This corresponds exactly to the proxy that is used by Gompers and Lerner (1996).

\footnotetext{
${ }^{29}$ See Gompers / Lerner (1996), pp. 466 and Gompers/Lerner (1999), pp. 7 ff. and 17; besides the fact, that the venture capital firm raised at least one fund, which was managed as professional that the investors will entrust this venture capitalists with capital again, the cumulative experience of all the involved individual managing directors can be taken as a proxy of the degree of experience and reputation of the venture capital firm. Often reputation of a managing team is strongly dependent on the reputation of its members. Unfortunately, statements about the history and experience of the individual managers associated with the fund are very heterogeneous. Whereas in some PPMs complete CV's of the managing directors are given, often the statements about the individual backgrounds are incomplete or missing. Furthermore, it is unclear how to compare the different former activities to build a appropriate measure of experience. A practical measure often used to represent the managers experience is their active time in a business, which relates to the business of venture capital financing. Even if this measure could be designed, only some PPMs provide detailed biographical information. The dataset would be reduced to a small number. To address this concern this measure of reputation should not be used as an separate independent variable, but may underline the quality of the variable "Non-Debut Fund" as a proxy for the managing venture capitalists' reputation. To assess reputation and experience we examined the cumulative time in business of the associated managing directors. 11 PPMs provide complete biographical information. The analysis shows the tendency that "Non-Debut Funds" are managed by venture capital teams, whose cumulative time in business exceeds the time, which was spend by "Debut Fund" manager teams in VC-business. The Pearson correlation coefficient of 0,69 is significant at the 5\% level (p-value: 0,017 / 2-tailed).

${ }^{30}$ See Gompers/Lerner (1999), pp. 8 Fn. 3, pp. 14 f. and (1996), pp. 475 f.; see also Franzke (2001), pp. 22.

${ }^{31}$ A long time in business not always implicates an overall high reputation and experience as well. Often venture capitalists were e.g., just consulting other VC-related businesses before they were raising their own fund. Sometimes, venture capitalists have just invested in some single companies and consider that as their time in business, even if they did not raise any real fund. They are, therefore, not obligatory experienced in financial contracting, if they are in business for a long time, and do not have a reputation in managing large funds.
} 
We include some variables to control for other factors that may influence contractual design. By doing that, we isolate the effects of reputation and bargaining measures. To exclude a potential time trend as a result of a professionalizing young European market we included the date of fund raising as a control variable. ${ }^{32}$ Furthermore, we assume differences between the Continental-European and Anglo-Saxon legal environments. Starting with LaPorta (1997) literature shows the influence of legal systems on the evolution of the capital markets. Glaeser and Shleifer (2001) examine whether the legal origin matters. They indicate on most measures that common law countries, like the Anglo-Saxon countries, appear to be more financially developed than countries belonging to the civil or Roman law tradition. This also becomes apparent on heavier property rights protection in Anglo-Saxon countries. ${ }^{33}$ The integration of a dummy variable which indicates Anglo-Saxon funds prevents possible distortions. Two further control dummy variables, that indicate early stage and non high-tech funds, filter out the need for stronger regulations and effects of higher administrative costs on contractual design. ${ }^{34}$ Gompers (1995) mentions a higher level of asymmetric information distribution between the VC-firm and early stage investments than between the VC-firm and later stage investments. The existence of no or only a short history of these companies complicates evaluating their business. More information about later stage investments and companies acting in well known business fields (with traditional product lines) lower the associated agency costs. ${ }^{35}$ Ruhnka/Young (1991) and (1987) concluded after a survey of 73 US-VC-firms a higher risk level for ventures in a lower development stage. Managerial and technological weaknesses have been detected as the major risk factors of early stage investments. ${ }^{36}$ The venture capitalist, therefore, is confronted with a closer monitoring and has to compensate these weaknesses by consulting the entrepreneur. ${ }^{37}$ Gompers (1995) has empirically assessed that the monitoring activity rises in situations with increasing asymmetric information distribution. ${ }^{38}$ The associated higher costs of running and administrating the fund may be beard by the investors' management fee payments. ${ }^{39}$ Within the context of agency problems between the limited partners and the venture capitalists Gompers and Lerner (1996) argue, that the funds' investment focus may be a relevant variable, which determine the potential for opportunistic behaviour. Managing directors of

\footnotetext{
${ }^{32}$ A low Pearson correlation of $-0,227$ between the time and the growth of the VC-pool indicates no correlation.

${ }^{33}$ See Glaeser/Shleifer (2001), pp. 1 and 33 f., see also Beck, Demirgüc-Kunt, Levine (2002).

${ }^{34}$ See Gompers/Lerner (1999), pp. $19 \mathrm{f}$.

35 See Gompers (1995), pp. 1463 and $1477 \mathrm{f}$.

36 See Ruhnka/Young (1991),pp. 121 and Ruhnka/Young (1987),pp.170 ff. and Bauer/Bilo/Zimmermann (2001), pp. 10.

${ }^{37}$ See Kaplan/Strömberg (2001), pp. 6.

38 See also Tykvova (2000), pp. 7.

39 See Gompers/Lerner (1999), pp. 8.
} 
early-stage and high-technology funds may have more scope to engage in opportunistic behaviour. $^{40}$ This may strongly affect the contractual design. Monetary incentives given by performance related compensation (carried interest) and capital contribution of the managing directors may reduce opportunistic activities. Covenants may provide a higher degree of control and may restrict the actions of the venture capitalist. ${ }^{41}$ By implementing the control variables which indicate early stage and non-high tech focused funds the sole effects of reputation and bargaining power on contractual design are isolated.

Table 3 and 4 summarize the univariate comparisons for the management fee (as percentage on committed capital p.a.) and the NPV of the management fee (as percentage of the committed capital), respectively. We compare the mean values for funds with different characteristics referring to the funds' reputation, the time when the fund was closed, the legal origin, and the fund's focus. Furthermore, we compare the mean values of the funds which are above and below the median referring to time in business, the size of funds, and the growth of the VC-pool at the time of funds' closing.

\begin{tabular}{|c|c|c|c|c|}
\hline \multicolumn{5}{|l|}{ Management Fee } \\
\hline & Mean & Std. Deviation & $\begin{array}{r}\begin{array}{r}p-v a l u e \\
\text {-equal variances not } \\
\text { assumed- }\end{array} \\
\text { [Equal variances] } \\
\end{array}$ & $\begin{array}{r}\text { Test for } \\
\text { Equality of } \\
\text { variances: } \\
\text { p-value }\end{array}$ \\
\hline $\begin{array}{l}\text { Debut fund } \\
\text { Non-debut fund }\end{array}$ & $\begin{array}{l}0,2446[\mathrm{~N}=57] \\
0,2417[\mathrm{~N}=62]\end{array}$ & $\begin{array}{l}0,00586 \\
0,00270\end{array}$ & $\begin{array}{r}0,739 \\
{[0,733]}\end{array}$ & $0,011^{* *}$ \\
\hline $\begin{array}{l}\text { Time in business } \\
>\text { median } \\
<=\text { median }\end{array}$ & $\begin{array}{l}0,0236[\mathrm{~N}=56] \\
0,0249[\mathrm{~N}=63]\end{array}$ & $\begin{array}{l}0,00283 \\
0,00549\end{array}$ & $\begin{array}{l}0,093^{*} \\
{[0,104]}\end{array}$ & 0,395 \\
\hline $\begin{array}{l}\text { Size of VC-Fund } \\
>\text { median } \\
<=\text { median }\end{array}$ & $\begin{array}{l}0,0234[\mathrm{~N}=57] \\
0,0251[\mathrm{~N}=62]\end{array}$ & $\begin{array}{l}0,00263 \\
0,00557\end{array}$ & $\begin{array}{r}0,04^{\star *} \\
{\left[0,044^{\star *}\right]}\end{array}$ & 0,179 \\
\hline $\begin{array}{l}\text { Growth of VC-pool in year } \\
\text { of first closing } \\
>\text { median } \\
<=\text { median }\end{array}$ & $\begin{array}{l}0,0237[\mathrm{~N}=58] \\
0,0248[\mathrm{~N}=61]\end{array}$ & $\begin{array}{l}0,00372 \\
0,00506\end{array}$ & $\begin{array}{r}0,152 \\
{[0,155]}\end{array}$ & 0,784 \\
\hline $\begin{array}{l}\text { Year of closing } \\
2000-2001 \\
1996-1999\end{array}$ & $\begin{array}{l}0,0244[\mathrm{~N}=83] \\
0,0240[\mathrm{~N}=36]\end{array}$ & $\begin{array}{l}0,00414 \\
0,00523\end{array}$ & $\begin{array}{c}0,677 \\
{[0,647]}\end{array}$ & 0,098 \\
\hline $\begin{array}{l}\text { Anglo-Saxon legal origin } \\
\text { Continental-European origin }\end{array}$ & $\begin{array}{l}0,0237[\mathrm{~N}=30] \\
0,0245[\mathrm{~N}=89]\end{array}$ & $\begin{array}{l}0,00234 \\
0,00499\end{array}$ & $\begin{array}{r}0,270 \\
{[0,427]}\end{array}$ & 0,182 \\
\hline $\begin{array}{l}\text { Early stage } \\
\text { Non-early stage }\end{array}$ & $\begin{array}{l}0,251[\mathrm{~N}=70] \\
0,231[\mathrm{~N}=49]\end{array}$ & $\begin{array}{l}0,00427 \\
0,00455\end{array}$ & $\begin{array}{r}0,02^{\star *} \\
{\left[0,018^{\star \star}\right]}\end{array}$ & 0,148 \\
\hline $\begin{array}{l}\text { High-tech } \\
\text { Non-high-tech }\end{array}$ & $\begin{array}{r}0,2447[112] \\
0,2179[7]\end{array}$ & $\begin{array}{l}0,00451 \\
0,00313\end{array}$ & $\begin{array}{c}0,067^{*} \\
{[0,124]}\end{array}$ & 0,979 \\
\hline
\end{tabular}

Notes: The mean of the management fee (as percentage on committed capital p.a.) is compared for funds with different characteristics. The dataset includes 119 European VC-funds, for which complete data about the management fees were available. The dataset is divided by the funds' reputation, the funds' origin, and the funds' investment stage and sector. Furthermore, funds with several measures above the median are compared with funds below the median. Standard t-test is used as test for differences in means. The

\footnotetext{
${ }^{40}$ See Gompers, P. / Lerner, J. (1996), pp. 484.

${ }^{41}$ See Kaplan/ Strömberg (2001), pp.6 identified those contractual solutions in the context of financial contracting between venture capitalist and entrepreneurs. Sahlmann (1990), pp.513 indicated similar problems and contractual solutions between Venture Capitalist and both entrepreneur and investor.
} 
third column presents the p-values of the t-test, if equal variances are not assumed. The null hypothesis says that these distributions are identical. One, two and three asterisks indicate a rejection of the null hypothesis at the $10 \%, 5 \%$ and $1 \%$ level of significance, respectively. As extensions in brackets the p-values under assumption of equal variances are shown. The fourth column represents the Levene's test for equality of variances, with the null hypothesis saying that the distributions are identical.

Table 3: Univariate Comparisons 'Management Fee'

Despite a generally standardized management fee, some significant differences can be found, if the PPMs are divided by fund focus (stage and sector), time in business, and funds' size. A significantly higher management fee is charged by funds with early stage and hightech focus, by small funds, and by venture capitalists which are not active in business for a long time. Analysing the NPV of the management fee, univariate comparisons show the same significant differences for funds with different investment focuses (early/later stage and hightech/non-high-tech focus). The other differences cannot be confirmed. The NPV of the management fee, however, decreases significantly, if the fund was established at times of rapidly growing VC-inflows (table 4). This supports neither the bargaining power nor the reputation hypothesis. The bargaining power hypothesis is rejected. Under consideration of the superior importance of the NPV of the management fee as a measure of fixed fee commitments these results seem to be the only meaningful.

\begin{tabular}{|c|c|c|c|c|}
\hline \multicolumn{5}{|c|}{ Present Value of Management Fee over Funds' Life } \\
\hline & Mean & Std. Deviation & 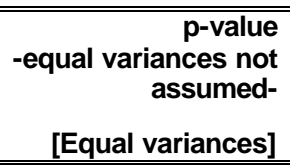 & $\begin{array}{r}\text { Test for } \\
\text { Equality of } \\
\text { variances: } \\
\text { p-value }\end{array}$ \\
\hline $\begin{array}{l}\text { Debut fund } \\
\text { Non-debut fund }\end{array}$ & $\begin{array}{l}0,1510 \\
0,1509\end{array}$ & $\begin{array}{l}0,0350 \\
0,0249\end{array}$ & $\begin{array}{r}0,976 \\
{[0,976]}\end{array}$ & 0,130 \\
\hline $\begin{array}{l}\text { Time in business } \\
>\text { median } \\
<=\text { median }\end{array}$ & $\begin{array}{l}0,1476 \\
0,1534\end{array}$ & $\begin{array}{l}0,0238 \\
0,0350\end{array}$ & $\begin{array}{r}0,288 \\
{[0,295]}\end{array}$ & $0,071^{*}$ \\
\hline $\begin{array}{l}\text { Size of VC-Fund } \\
>\text { median } \\
<=\text { median }\end{array}$ & $\begin{array}{l}0,1472 \\
0,1540\end{array}$ & $\begin{array}{l}0,0218 \\
0,0364\end{array}$ & $\begin{array}{r}0,223 \\
{[0,225]}\end{array}$ & $0,031^{* *}$ \\
\hline $\begin{array}{l}\text { Growth of VC-pool in year } \\
\text { of first closing } \\
>\text { median } \\
<=\text { median }\end{array}$ & $\begin{array}{l}0,1450 \\
0,1566\end{array}$ & $\begin{array}{l}0,0280 \\
0,0310\end{array}$ & $\begin{array}{l}0,035^{\star \star} \\
{\left[0,036^{\star \star}\right]}\end{array}$ & 0,602 \\
\hline $\begin{array}{l}\text { Year of closing } \\
2000-2001 \\
1996-1999\end{array}$ & $\begin{array}{l}0,1515 \\
0,1495\end{array}$ & $\begin{array}{l}0,0285 \\
0,0336\end{array}$ & $\begin{array}{r}0,759 \\
{[0,742]}\end{array}$ & 0,271 \\
\hline $\begin{array}{l}\text { Anglo-Saxon legal origin } \\
\text { Continental-European origin }\end{array}$ & $\begin{array}{l}0,1438 \\
0,1533\end{array}$ & $\begin{array}{l}0,0211 \\
0,0322\end{array}$ & $\begin{array}{l}0,067^{*} \\
{[0,132]}\end{array}$ & 0,245 \\
\hline $\begin{array}{l}\text { Early stage } \\
\text { Non-early stage }\end{array}$ & $\begin{array}{l}0,1570 \\
0,1422\end{array}$ & $\begin{array}{l}0,0255 \\
0,0339\end{array}$ & $\begin{array}{r}\left.0,011^{* *}\right] \\
{\left[0,007^{* * *}\right]}\end{array}$ & 0,141 \\
\hline $\begin{array}{l}\text { High-tech } \\
\text { Non-high-tech }\end{array}$ & $\begin{array}{l}0,1525 \\
0,1297\end{array}$ & $\begin{array}{l}0,02887 \\
0,03900\end{array}$ & $\begin{array}{c}0,121 \\
{\left[0,021^{* *}\right]}\end{array}$ & 0,245 \\
\hline
\end{tabular}

Notes: The net present value of the management fee over funds' life (as percentage on committed capital) is compared for funds with different characteristics. The dataset includes 119 European VC-funds, for which complete data about the management fees were available. For more details see notes of table 3.

Table 4: Univariate Comparisons 'NPV of Management Fee'

Univariate analyses show no significant variations of the hurdle rate if the sample is divided by the known measures (table 5). 


\begin{tabular}{|c|c|c|c|c|}
\hline \multicolumn{5}{|l|}{ Hurdle Rate } \\
\hline & Mean & Std. Deviation & $\begin{array}{r}\begin{array}{r}p-v a l u e \\
\text {-equal variances not } \\
\text { assumed- }\end{array} \\
\text { [Equal variances] } \\
\end{array}$ & $\begin{array}{r}\text { Test for } \\
\text { Equality of } \\
\text { variances: } \\
\text { p-value }\end{array}$ \\
\hline $\begin{array}{l}\text { Debut fund } \\
\text { Non-debut fund }\end{array}$ & $\begin{array}{r}0,0390[\mathrm{~N}=58] \\
0,033[\mathrm{~N}=64]\end{array}$ & $\begin{array}{l}0,0356 \\
0,0390\end{array}$ & $\begin{array}{r}0,424 \\
{[0,424]}\end{array}$ & 0,551 \\
\hline $\begin{array}{l}\text { Time in business } \\
>\text { median ( } 2 \text { years }) \\
<=\text { median }\end{array}$ & $\begin{array}{l}0,033[\mathrm{~N}=57] \\
0,039[\mathrm{~N}=62]\end{array}$ & $\begin{array}{l}0,0384 \\
0,0390\end{array}$ & $\begin{array}{r}0,342 \\
{[0,343]}\end{array}$ & 0,947 \\
\hline $\begin{array}{l}\text { Size of VC-Fund } \\
>\text { median }(€ 75,55 \text { Mio) } \\
<=\text { median }\end{array}$ & $\begin{array}{l}0,034[\mathrm{~N}=60] \\
0,038[\mathrm{~N}=60]\end{array}$ & $\begin{array}{l}0,0392 \\
0,0382\end{array}$ & $\begin{array}{l}0,543 \\
0,543\end{array}$ & 0,854 \\
\hline $\begin{array}{l}\text { Growth of vc-pool in year of } \\
\text { first closing } \\
>\text { median }(60,69 \%) \\
<=\text { median }\end{array}$ & $\begin{array}{l}0,031[\mathrm{~N}=58] \\
0,039[\mathrm{~N}=64]\end{array}$ & $\begin{array}{l}0,0371 \\
0,0401\end{array}$ & $\begin{array}{r}0,428 \\
{[0,430]}\end{array}$ & 0,200 \\
\hline $\begin{array}{l}\text { Year of closing } \\
2000-2001 \\
1996-1999\end{array}$ & $\begin{array}{l}0,038[\mathrm{~N}=85] \\
0,030[\mathrm{~N}=37]\end{array}$ & $\begin{array}{l}0,0385 \\
0,0447\end{array}$ & $\begin{array}{r}0,348 \\
{[0,304]}\end{array}$ & 0,217 \\
\hline $\begin{array}{l}\text { Anglo-Saxon legal origin } \\
\text { Continental-European origin }\end{array}$ & $\begin{array}{l}0,038[\mathrm{~N}=31] \\
0,035[\mathrm{~N}=91]\end{array}$ & $\begin{array}{l}0,0428 \\
0,0374\end{array}$ & $\begin{array}{r}0,791 \\
{[0,776]}\end{array}$ & 0,173 \\
\hline $\begin{array}{l}\text { Early stage } \\
\text { Non-early stage }\end{array}$ & $\begin{array}{l}0,0317[\mathrm{~N}=72] \\
0,0428[\mathrm{~N}=50]\end{array}$ & $\begin{array}{l}0,0369 \\
0,0406\end{array}$ & $\begin{array}{r}0,114 \\
{[0,108]}\end{array}$ & 0,153 \\
\hline $\begin{array}{l}\text { High-tech } \\
\text { Non-high-tech }\end{array}$ & $\begin{array}{r}0,035[\mathrm{~N}=115] \\
0,051[\mathrm{~N}=7]\end{array}$ & $\begin{array}{l}0,0389 \\
0,0351\end{array}$ & $\begin{array}{r}0,296 \\
{[0,303]}\end{array}$ & 0,208 \\
\hline
\end{tabular}

Notes: The mean of the hurdle rate is compared for funds with different characteristics. The dataset includes 122 European VC-funds, for which complete data about the management fees were available. For more details see notes of table 3 .

Table 5: Univariate Comparisons 'Hurdle Rate'

\begin{tabular}{|c|c|c|c|c|}
\hline \multicolumn{5}{|l|}{ Carry option value } \\
\hline & Mean & Std. Deviation & $\begin{array}{c}\text { p-value } \\
\text {-equal variances not } \\
\text { assumed- } \\
\text { [Equal variances] }\end{array}$ & $\begin{array}{r}\text { Test for } \\
\text { Equality of } \\
\text { variances: } \\
\text { p-value }\end{array}$ \\
\hline $\begin{array}{l}\text { Debut fund } \\
\text { Non-debut fund }\end{array}$ & $\begin{array}{l}0,1546[\mathrm{~N}=57] \\
0,1513[\mathrm{~N}=63]\end{array}$ & $\begin{array}{r}0,0107 \\
0,024\end{array}$ & $\begin{array}{r}0,338 \\
{[0,321]}\end{array}$ & 0,365 \\
\hline $\begin{array}{l}\text { Time in business } \\
>\text { median ( } 2 \text { years) } \\
<=\text { median }\end{array}$ & $\begin{array}{l}0,1527[\mathrm{~N}=57] \\
0,1533[\mathrm{~N}=61]\end{array}$ & $\begin{array}{l}0,0219 \\
0,0148\end{array}$ & $\begin{array}{r}0,866 \\
{[0,864]}\end{array}$ & 0,727 \\
\hline $\begin{array}{l}\text { Size of VC-Fund } \\
>\text { median }(€ 75,55 \text { Mio) } \\
<=\text { median }\end{array}$ & $\begin{array}{l}0,1520[\mathrm{~N}=58] \\
0,1540[\mathrm{~N}=60]\end{array}$ & $\begin{array}{l}0,0210 \\
0,0158\end{array}$ & $\begin{array}{r}0,555 \\
{[0,553]}\end{array}$ & 0,717 \\
\hline $\begin{array}{l}\text { Growth of vc-pool in year of } \\
\text { first closing } \\
>\text { median }(60,69 \%) \\
<=\text { median }\end{array}$ & $\begin{array}{l}0,1081[\mathrm{~N}=58] \\
0,1069[\mathrm{~N}=63]\end{array}$ & $\begin{array}{r}0,007 \\
0,0168\end{array}$ & $\begin{array}{r}0,591 \\
{[0,602]}\end{array}$ & 0,097 \\
\hline $\begin{array}{l}\text { Year of closing } \\
2000-2001 \\
1996-1999\end{array}$ & $\begin{array}{l}0,1527[\mathrm{~N}=83] \\
0,1517[\mathrm{~N}=36]\end{array}$ & $\begin{array}{l}0,0181 \\
0,0147\end{array}$ & $\begin{array}{r}0,745 \\
{[0,764]}\end{array}$ & 0,988 \\
\hline $\begin{array}{l}\text { Anglo-Saxon legal origin } \\
\text { Continental-European origin }\end{array}$ & $\begin{array}{l}0,1558[\mathrm{~N}=30] \\
0,1521[\mathrm{~N}=90]\end{array}$ & $\begin{array}{l}0,0131 \\
0,0198\end{array}$ & $\begin{array}{r}0,257 \\
{[0,351]}\end{array}$ & 0,656 \\
\hline $\begin{array}{l}\text { Early stage } \\
\text { Non-early stage }\end{array}$ & $\begin{array}{l}0,1536[\mathrm{~N}=71] \\
0,1522[\mathrm{~N}=49]\end{array}$ & $\begin{array}{l}0,0212 \\
0,0134\end{array}$ & $\begin{array}{r}0,661 \\
{[0,685]}\end{array}$ & 0,316 \\
\hline $\begin{array}{l}\text { High-tech } \\
\text { Non-high-tech }\end{array}$ & $\begin{array}{r}0,1531[\mathrm{~N}=113] \\
0,1522[\mathrm{~N}=7]\end{array}$ & $\begin{array}{r}0,0189 \\
0,000\end{array}$ & $\begin{array}{r}0,624 \\
{[0,903]}\end{array}$ & 0,435 \\
\hline
\end{tabular}

Notes: The mean of the hurdle rate is compared for funds with different characteristics. The dataset includes 120 European VC-funds, for which complete data about the management fees were available. For more details see notes of table 3.

Table 6: Univariate Comparisons 'Carry Option Value' 
Similar to the level of the carried interest, there is no large variation around the carry option values' mean. Therefore, univariate comparisons presented in table 6 with the options' value of performance related compensation as dependent variable do not show significant differences.

Table 7 summarizes the univariate comparisons of the capital contributions done by the venture capitalists. Despite the varying amount of capital contributions made by the managers of the different funds, we found no significant differences in the mean of the amount of capital contribution, if the dataset is divided by the known measures.

\begin{tabular}{|c|c|c|c|c|}
\hline \multicolumn{5}{|l|}{ Capital contribution } \\
\hline & Mean & Std. Deviation & $\begin{array}{r}\begin{array}{r}p-v a l u e \\
\text {-equal variances not } \\
\text { assumed- }\end{array} \\
\text { [Equal variances] } \\
\end{array}$ & $\begin{array}{r}\text { Test for } \\
\text { Equality of } \\
\text { variances: } \\
\text { p-value }\end{array}$ \\
\hline $\begin{array}{l}\text { Debut fund } \\
\text { Non-debut fund }\end{array}$ & $\begin{array}{l}0,0148[\mathrm{~N}=22] \\
0,0158[\mathrm{~N}=24]\end{array}$ & $\begin{array}{l}0,0366 \\
0,0402\end{array}$ & $\begin{array}{r}0,932 \\
{[0,933]}\end{array}$ & 0,922 \\
\hline $\begin{array}{l}\text { Time in business } \\
>\text { median }(2,5 \text { years }) \\
<=\text { median }\end{array}$ & $\begin{array}{l}0,0169[\mathrm{~N}=23] \\
0,0137[\mathrm{~N}=23]\end{array}$ & $\begin{array}{l}0,0416 \\
0,0315\end{array}$ & $\begin{array}{r}0,782 \\
{[0,782]}\end{array}$ & 0,678 \\
\hline $\begin{array}{l}\text { Size of VC-Fund } \\
>\text { median ( } € 73,32 \text { Mio) } \\
<=\text { median }\end{array}$ & $\begin{array}{l}0,0145[\mathrm{~N}=23] \\
0,0161[\mathrm{~N}=23]\end{array}$ & $\begin{array}{l}0,0408 \\
0,0360\end{array}$ & $\begin{array}{r}0,888 \\
{[0,888]}\end{array}$ & 0,775 \\
\hline $\begin{array}{l}\text { Growth of vc-pool in year of } \\
\text { first closing } \\
>\text { median }(61,46 \%) \\
<=\text { median }\end{array}$ & $\begin{array}{l}0,0078[\mathrm{~N}=21] \\
0,0216[\mathrm{~N}=25]\end{array}$ & $\begin{array}{l}0,00941 \\
0,05060\end{array}$ & $\begin{array}{r}0,193 \\
{[0,225]}\end{array}$ & $0,019^{\star *}$ \\
\hline $\begin{array}{l}\text { Year of closing } \\
2000-2001 \\
1996-1999\end{array}$ & $\begin{array}{l}0,0149[\mathrm{~N}=27] \\
0,0159[\mathrm{~N}=19]\end{array}$ & $\begin{array}{l}0,0381 \\
0,0391\end{array}$ & $\begin{array}{r}0,932 \\
{[0,931]}\end{array}$ & 0,728 \\
\hline $\begin{array}{l}\text { Anglo-Saxon legal origin } \\
\text { Continental-European origin }\end{array}$ & $\begin{array}{l}0,0110[\mathrm{~N}=10] \\
0,0165[\mathrm{~N}=36]\end{array}$ & $\begin{array}{l}0,0145 \\
0,0425\end{array}$ & $\begin{array}{r}0,515 \\
{[0,689]}\end{array}$ & 0,278 \\
\hline $\begin{array}{l}\text { Early stage } \\
\text { Non-early stage }\end{array}$ & $\begin{array}{l}0,0246[\mathrm{~N}=23] \\
0,0061[\mathrm{~N}=23]\end{array}$ & $\begin{array}{l}0,0525 \\
0,0060\end{array}$ & $\begin{array}{c}0,106 \\
{\left[0,10^{*}\right]}\end{array}$ & 0,004 \\
\hline $\begin{array}{l}\text { High-tech } \\
\text { Non-high-tech }\end{array}$ & $\begin{array}{r}0,0155[\mathrm{~N}=45] \\
0,0100[\mathrm{~N}=1]\end{array}$ & 0,0385 & {$[0,889]$} & \\
\hline
\end{tabular}

The univariate comparisons of the number of restrictions and regulations are summarized in table 8. The results show some significant differences in the mean number of covenants, if the dataset is divided by two measures suggested by the reputation hypothesis. "Non-debut funds" have a significantly higher restrictiveness. These differences are significant at the $1 \%$ level. Large funds also include more covenants. This is significant on a 5\% level. These results reject the assumptions made by the reputation hypothesis. Furthermore, we can find dependencies from the date of contracting and according to the funds' legal origin. 


\begin{tabular}{|c|c|c|c|c|}
\hline \multicolumn{5}{|l|}{ Number of Covenants } \\
\hline & Mean & "Std. Deviation & $\begin{array}{r}\text { p-value } \\
\text {-equal variances not } \\
\text { assumed- } \\
\text { [Equal variances] } \\
\end{array}$ & $\begin{array}{r}\text { Test for } \\
\text { Equality of } \\
\text { variances: } \\
\text { p-value }\end{array}$ \\
\hline $\begin{array}{l}\text { Debut fund } \\
\text { Non-debut fund }\end{array}$ & $\begin{array}{l}3,1[\mathrm{~N}=22] \\
5,7[\mathrm{~N}=24]\end{array}$ & $\begin{array}{l}3,16 \\
2,54\end{array}$ & $\begin{array}{r}0,005^{\star \star *} \\
{\left[0,004^{* \star *}\right]}\end{array}$ & 0,115 \\
\hline $\begin{array}{l}\text { Time in business } \\
>\text { median }(2,5 \text { years }) \\
<=\text { median }\end{array}$ & $\begin{array}{l}5,1[\mathrm{~N}=23] \\
3,8[\mathrm{~N}=23]\end{array}$ & $\begin{array}{l}2,96 \\
3,17\end{array}$ & $\begin{array}{r}0,171 \\
{[0,171]}\end{array}$ & 0,243 \\
\hline $\begin{array}{l}\text { Size of VC-Fund } \\
>\text { median }(€ 73,32 \mathrm{Mio}) \\
<=\text { median }\end{array}$ & $\begin{array}{l}5,6[\mathrm{~N}=23] \\
3,4[\mathrm{~N}=23]\end{array}$ & $\begin{array}{l}2,79 \\
3,08\end{array}$ & $\begin{array}{r}0,018^{\star *} \\
{\left[0,018^{\star \star}\right]}\end{array}$ & 0,381 \\
\hline $\begin{array}{l}\text { Growth of vc-pool in year of } \\
\text { first closing } \\
>\text { median }(61,46 \%) \\
<=\text { median }\end{array}$ & $\begin{array}{l}4,8[\mathrm{~N}=28] \\
3,9[\mathrm{~N}=18]\end{array}$ & $\begin{array}{l}3,00 \\
3,25\end{array}$ & $\begin{array}{r}0,335 \\
{[0,325]}\end{array}$ & 0,990 \\
\hline $\begin{array}{l}\text { Year of closing } \\
2000-2001 \\
1996-1999\end{array}$ & $\begin{array}{l}5,3[\mathrm{~N}=27] \\
3,3[\mathrm{~N}=19]\end{array}$ & $\begin{array}{l}2,75 \\
3,28\end{array}$ & $\begin{array}{l}0,042^{\star *} \\
0,035^{\star *}\end{array}$ & 0,257 \\
\hline $\begin{array}{l}\text { Anglo-Saxon legal origin } \\
\text { Continental-European origin }\end{array}$ & $\begin{array}{l}6,7[\mathrm{~N}=10] \\
3,8[\mathrm{~N}=36]\end{array}$ & $\begin{array}{l}3,53 \\
2,70\end{array}$ & $\begin{array}{r}0,035^{* *} \\
{\left[0,008^{* * *}\right]}\end{array}$ & 0,438 \\
\hline $\begin{array}{l}\text { Early stage } \\
\text { Non-early stage }\end{array}$ & $\begin{array}{l}4,3[\mathrm{~N}=23] \\
4,7[\mathrm{~N}=23]\end{array}$ & $\begin{array}{l}2,71 \\
3,49\end{array}$ & $\begin{array}{r}0,674 \\
{[0,674]}\end{array}$ & 0,166 \\
\hline $\begin{array}{l}\text { High-tech } \\
\text { Non-high-tech }\end{array}$ & $\begin{array}{r}4,5[\mathrm{~N}=45] \\
2,0[\mathrm{~N}=1]\end{array}$ & 3,11 & {$[0,43]$} & \\
\hline
\end{tabular}

Notes: The mean of the number of included covenants is compared for funds with different characteristics. The dataset includes 46 European VC-funds, for which complete data about the management fees were available. For more details see notes of table 3.

Table 8: Univariate Comparisons 'Number of Covenants'

\section{c. Multivariate analyses}

We examined the determinants of the NPV of the management fee, the performance sensitivity, and the number of covenants (out of a total of 14) by applying a regression analysis with the econometric specification of ordinary least square. We analysed, however, the determinants of the hurdle rates by employing both the econometric specification of ordinary least square and the LOGIT-Model. For the OLS regression analysis we used the level of the received hurdle rate (preferred return on committed capital p.a.) as the dependent variable. Furthermore, we examined the determinants of a managing directors' obligation for a capital contribution by applying the Logit Model. The Logit-Models are employed determining the probability of the existence of any hurdle rate or any obligated capital contribution. Since the variation of the level of capital contribution is not normally distributed the econometric specification of OLS regression cannot be used. To avoid disturbing effects of multicollinearity we did the regression analyses more than once dropping some explanatory variables with linear relationship. Since in any case the results do not change significantly we can not observe strong effects of multicollinearity. Results are presented in table 9, 10 and 11, page 36 . 
Table 9 presents the OLS regressions with the number of included covenants as the dependent variables. We have done the analysis of covenants twice with two alternative dependent variables. First, we examined the influence of the determinants on the number of included covenants. Next, we tested the robustness of the results by replacing the dependent variable by a weighted number of covenants. Even if, in general, the meanings of the same covenants correspond to each other, the particular covenants can have different characteristics. The covenants are not standardized and differ with regard to the degree of restrictiveness. Whereas for example one partnership restricts leverage completely another partnership allows a leverage of 30\%. Both partnership agreements include this covenant, but the level of restrictiveness is completely different. The analysis can be distorted if an all-ornothing covenant inclusion is assumed. To address this concern we weight the covenants: the restriction on the size of investment in one firm is weighted with $\omega=1$, if the allowed maximum investment size is not exceeding $25 \%$ of the committed capital (otherwise $\omega=0$ ). We weighted all other covenants, which prescribe a certain level of restrictiveness like the restriction on the use of debt with $\omega=[100 \%$ - percentage of committed capital that can be used for the particular action]. Except these covenants that give subjectively limited restriction $(\omega=0,5)$, all other covenants are weighted with $\omega=1$, if they are included. The results of both regression analyses mainly correspond to each other.

Table 10 presents the results of the regression analyses with the NPV of management fee and the performance sensitivity of the compensation as the dependent variables. Finally, table 11 presents the results of the Logit Models and OLS regression with the venture capitalists' obligation for a capital contribution and the hurdle rate as dependent variables.

\section{i. Effects of reputation on contractual design}

We test whether the independent variable, non-debut manager that proxy for high reputation of the funds' manager differs from zero. Table 9 presents the effect of reputation on the use of covenants. The coefficient of the dummy variable characterizing non-debut fund managers is significantly positive. There are no significant influences by the other control variables which are used as inferior proxies of reputation. The reputation hypothesis is rejected on a $1 \%$ level of significance (on a $5 \%$ level of significance if the weighted number of covenants is used as dependent variable). Empirical results show that European fund managers who managed at least one fund before are more restricted than debut fund managers. This contradicts the assumption of the reputation hypothesis. The usual theoretical 
assumptions are not met. Reputation seems not to be seen as an additional security for the investor that allows the venture capitalists to reduce his own restrictiveness.

Why do empirical results in the VC-market not show the usual effects of reputation on contracting? Why is higher reputation a driver of an increased restrictiveness? Aghion and Bolton (1992) analysed contractual incompleteness under consideration of different wealth constraints of the entrepreneur (as the agent: in our case the venture capitalist) and outside investors (as the principal). They suggest that "both have potentially conflicting objectives since the entrepreneur cares about both pecuniary and non-pecuniary returns from the project while the investor is only concerned about monetary returns." 42 The theoretical framework of the reputation hypothesis assumed the following: not all potential conflicts have to be resolved by ex ante contracting if a potential loss of reputation gives incentives to work according to the investors' interests. The maintenance of a good reputation is considered as a non-pecuniary return. This, however, seems only to be true if there involved parties have an infinite time horizon and the importance of that non-pecuniary return does not decrease over time.

In the VC-business, there are different governance structures which implicate different motivation pattern and may allow another interpretation. Usually, the business of a VCcompany is done by just a certain number of general partners with restricted active time in business. Their wealth and financial situations change over the years. While managing their first fund they have to gain reputation which is an important factor for follow on fund raising with larger sizes. Initially, they have to work hard to gain that reputation. Later, if they had raised lots of funds their incentives to hold reputation may decrease, because their time in business is going to end. Their wealth situation changed and they do not have to rely on reputation as the key for building up their business. An ending time in business reduces the value of reputation as an additional security for the investor. ${ }^{43}$ In the VC-market, this changing incentive situation has effects on contractual restrictiveness. Our argumentation is similar to that given by the learning model of Gompers and Lerner. As a result however, they assume changing incentive compensation. In Europe, we give empirical evidence that different inherent incentive situations do not affect compensation schemes, but the contractual restrictiveness.

\footnotetext{
${ }^{42}$ See Aghion/Bolton (1992), pp. 473.

${ }^{43}$ This interpretation concerns to the learning model of Gompers and Lerner. Furthermore, example calculations of the revenues per general partners are given by Sahlmann (1990), pp $494 \mathrm{ff}$. It is shown in how far the GPs wealth situation changes if they were able to manage at least one fund successfully.
} 
For European partnership agreements the empirical results show only little evidence that reputation affects compensation terms. There is no significant effect on the fixed fees over funds' life, on the performance sensitivity of the compensation, and the hurdle rate (table 10 and 11). We conclude that reputation does not seem to affect compensation. The results in the first panel of table 11, however, show that the proxy for reputation is important in determining the existence of a contractual obligation for the general managers to make capital contributions. Empirical results show that non-debut fund manager with higher reputation are more often obligated to make a capital contribution than first time fund managers (5\% level of significance). This is consistent with the assumptions of the learning model. This model assumed that there should be a higher need for monetary incentives for fund managers with good reputation. Furthermore, this result confirms the interpretation made above. When established funds care less about their reputation, stronger performance related incentives may be used side by side with more restrictive covenants in order to prevent opportunistic behaviour. Of course, there is another possible interpretation: managers of established funds are often wealthier than managers of debut funds and may find it easier to make capital contributions.

\section{ii. Effects of bargaining power on contractual design}

As tables 9 and 10 show, the variable that measures the growth rate of the venture pool has a significant effects on compensation, but not on the number of restrictive covenants. In years with a strongly growing VC-pool the demanded fixed fees decline. The bargaining power hypothesis is rejected on a $1 \%$ significance level. ${ }^{44}$ According to highly standardized carried interest payments, the performance sensitivity is likely to increase in times the managers have high bargaining power. The results that are presented in panel 2 of table 10 are not consistent with the theoretical assumptions, either. Concerning the performance sensitivity the bargaining power hypothesis is rejected on a $10 \%$ and $5 \%$ significance level. Table 11 shows the effects of high bargaining power on the contracted hurdle rates and the capital contribution obligations. The bargaining power proxy significantly lowers the hurdle rate. This is confirmed by the OLS regression on a $10 \%$ level of significance and by the Logit

\footnotetext{
${ }^{44}$ The results of the regression analysis are even confirmed, if the NPV of the management fee is calculated in the following way: The annually management fee payments (as the percentage on committed capital) are discounted only over this period of time, which is fixed in the partnership agreement (or in the PPM, if the PA is not available). If a life time extension is allowed, the management fees of the corresponding years are discounted with the increased rate of $20 \%$. The OLS regression leads to the same signs of the coefficients and the null hypotheses of no difference are rejected for the same variables.
} 
Model on a $5 \%$ significance level. The obligation to make a capital contribution is not affected by the supply/demand situation.

Most of these results, except those concerning the hurdle rate, reject the bargaining power hypothesis. However, the effects of increasing bargaining power on compensation terms are jointly consistent and can be interpreted: As a result of lower fixed charges, the importance of performance related earnings as a part of the overall management compensation is rising. This is indicated by an increasing sensitivity of compensation to the performance. Our empirical results show that in times with a large VC-pool growth decreasing hurdle rates increase the value of the venture capitalists' carry option and intensify the importance of variable compensation. To test robustness of these results, we exchange the level of carried interest by the carried interest options' value measuring the individual sensitivity of compensation. Table 10 panel 3 presents the results that confirm our former findings: in times with a growing VC-pool, sensitivity of compensation to performance is increasing ( $10 \%$ or $5 \%$ level of significance). We recognize that venture capitalists with high bargaining power do not try to fix a higher amount of compensation for future times, but trust in performance related earnings. They believe in their future performance. This effect can be interpreted as a kind of overconfidence in times of growing markets. ${ }^{45}$ Hvide (2000) summarizes several studies from psychology and experimental economics indicating that agents are overconfident about their own abilities. This can hardly be explained by any rational formation. ${ }^{46}$ The findings of Camerer and Lovallo (1999) determine that overconfidence leads to excessive business entry. While analysing the impact of CEOs' overconfidence on mergers and acquisitions, Malmendier and Tate (2002) suggested that overconfident CEOs over-estimate their ability to generate returns. They found that overconfidence has the largest effect in firms with most cash. ${ }^{47}$ Kyle and Wang (1997) predict that an overconfident trader trades more aggressively than his rational opponent. ${ }^{48}$ This even $^{2}$

\footnotetext{
${ }^{45}$ We see overconfidence also in the variation of the total compensation (NPV of management fee + option value carry). In times with a growing vc-pool it is also significantly decreasing. Only higher capital gains could compensate this decrease. See Table 10 Panel 4

${ }^{46}$ See Hvide (2000), pp. 1 and 17, also Weinstein (1980), Taylor/Brown (1988).

${ }^{47}$ See Malmendier, / Tate (2002), pp. 1.

${ }^{48}$ See Kyle and Wang (1997), pp. 2074; as a result, they assume that the overconfident trader makes a higher expected profit and utility as his rational opponent. Referring to the changing venture capitalists attitude towards the way of fund managing and the changing preferred form of compensation, Sahlmann (1990), pp $496 \mathrm{ff}$. suggests the inherent agency problem of higher valued carry options: ,if one party has a contingent claim on value, there is an implicit incentive to increase risk". Analysing 2600 investments done between the years 1972 and 2002 of 60 funds of 32 venture capital companies [CEPRES Center of Private Equity Research] we found empirical evidence. If we assume identically independently distributed investments, the results of univariate comparisons indicate a significantly higher mean return but also higher volatility of investments that were done in times with high capital commitments. The mean IRR of investments that were
} 
seems to affect the compensation schemes. Literature about the effects of overconfidence predicts that overconfident managers will prefer performance based incentive schemes more often than standard theory predicts. ${ }^{49}$ Allen and Lueck (1995) found some evidence that this effect of overconfidence on the incentive design of contracts may be right. ${ }^{50}$ All these general findings correspond to the results of our study. In times with a growing VC-pool, this means increasing cash inflows but a relatively constant number of fund managers, we can see indications of the discussed management-overconfidence. The fund managers lower the investment hurdles by lowering fixed charges and, therefore, ease business entry. Driven by the actually good market situation they are confident to compensate the lower fixed charges by performance related earnings. They expect higher future performance for themselves. As a result, they prefer to be paid by more sensitive compensation. We recognize a change to the riskier variable form of management compensation. This suits the generally more aggressive trading attitude of overconfident fund managers.

\section{iii. Other factors}

The results of table 9, 10, and 11 indicate, that there is no significant time trend. The time trend variable adds little explanatory power to other variables. The legal origin of the VCcompany, however, has a strong impact on contract design. Anglo-Saxon fund managers are confronted with a stronger restrictiveness. This corresponds to the literature and our assumptions made above. The legal environment of common law in Anglo-Saxon countries directly influences the property rights protection done by the implementation of more covenants.

Overall, we find a more sophisticated use of covenants by non-debut funds and in mature Anglo-Saxon markets. Next to our former interpretation based on different incentive aspects between debut and non-debut fund manager and based on the effects of different legal origins, Kaplan / Martel / Strömberg (2002) considered another explanation of those empirical findings: the experience of the venture capitalists and the maturity of the markets may influence the contractual design. Especially first time VC-managers or those acting in a new market with legal and institutional impediments to contracting may need time in order to learn to structure contracts in that environment. It may take some time before the market

done in times with capital commitments above the median is $66.61 \%$, in times with capital inflows below the median $4.1 \%$. St Deviation in times with high capital commitments is $819 \%$, in times with low commitments $69 \%$. The null hypothesis of equal mean IRRs is rejected on a $1 \%$ level of significance. This results are robust to any variation of the dataset, e.g. if only realized investments without a valuation are basis of calculations.

${ }^{49}$ See Camerer / Lueck (1999), pp. 306 and 315.

${ }^{50}$ See Allen / Lueck (1995). 
participants converge to an optimal contractual design. ${ }^{51}$ Initially, the transaction costs of writing sophisticated contracts including sufficient covenants are higher. This leads to a larger incompleteness of contracts with a lower number of included covenants. In Europe, we found empirical evidence.

Finally, as we assumed before early stage and high tech focused funds charge higher fixed fees to compensate higher administrative costs (table 10, panel 1). The coefficients of the corresponding control variables are significantly different from zero (at least 5\% level of significance). However, there is no definite significant proof whether those funds have lower incentive compensation. Though highly standardized carried interest payments and higher fixed management fees, high tech funds do not have significantly lower performance sensitivity in compensation (table 10, panel 2 and 3). Furthermore, we found no effects on other compensation terms and on contractual restrictiveness (table 9 and 11).

\section{Comparison of US and European empirical findings}

Our results indicate strong differences in the way how reputation and bargaining power determine the design of US and European partnership agreements.

We find empirical evidence that there are different determinants of contractual restrictiveness in the US and in Europe. In the US, the number of included covenants is significantly influenced by the supply/demand situation for VC-services. Fund manager use their bargaining power in growth years to reduce contractual restrictiveness. In Europe, we found no evidence that growing bargaining power affects the completeness of contracts. We showed that reputation is the determinant which affects the use of covenants. The existence of different inherent incentives that are given to managers with or without reputation is adjusted by different contractual regulations.

Compensation terms are also influenced by different determinants. In the US, the fund managers' reputation affects both the NPV of management fees and the performance sensitivity of compensation. Young debut funds receive a larger fixed compensation and less performance related compensated. This may be explained by the fact that unknown young fund managers' work harder anyway in order to gain reputation. Highly incentive orientated

\footnotetext{
${ }^{51}$ See Kaplan / Martel / Strömberg (2002), pp. 4 ff.; in addition, table 3, 4, and 6 show higher variations of the management fee and the NPV of management fee between the samples' funds in Continental-Europe than in Anglo-Saxon countries and if it is charged by debut funds. This is a sign of a lower level of professionalization and optimal contract design. These findings confirm the assumption made by Kaplan et al. For further analyses see Feinendegen/ Schmidt/ Wahrenburg (2003), pp.21.
} 
compensation is not necessary. In Europe, we find less evidence that higher incentive compensation corrects inherent incentive gaps of fund managers with high reputation. Management fee or carried interest are not related to the reputation of the venture capitalist.

For the recent years of European VC-market development and for the US VC-market between 1972 and 1992, empirical results indicate different market mechanisms. Since the supply/demand situation for VC-services in the US affects the contractual restrictiveness and in Europe it influences the monetary price which has to be paid for these services, the price system seems better to work in Europe. Varying inherent working incentives for fund managers with or without reputation are adjusted in the US by changing monetary incentives and in Europe by changing contractual restrictiveness. Through effects on different contractual elements, in Europe and in the US the general assumptions of the learning model are confirmed.

\section{Summary and outlook}

The similar development of the US-American and the European VC markets of the early 80ties and the mid 90ties, respectively, provides an attractive basis for analysing European market standards and comparing them to preceding US trends. In this paper, we empirically analyse the contractual relations between European venture capital funds and investors. We explore those contractual arrangements that are used to regulate the principal agent relationship between investors and fund-management. Contractual key elements are certain covenants, which restrict the venture capitalists from opportunistic behaviour, and compensation terms. In respect to compensation, our analysis refers to the management fee, the carried interest and its call option value, the hurdle rate, and the fund managers' obligation to make their own capital contribution.

To expose market reactions in the VC-market, we examine the economical effect of two determinants on contractual design: the agents' reputation and bargaining power. We develop empirical evidence that the effect of these determinants on the design of contracts does not completely correspond to general theoretical approaches. In the VC-business, markets seem to work different.

Regarding the question how VC-markets are working, we found empirical evidence. Our findings indicate a substantial impact of the managers' reputation and bargaining power on contractual design. Contrary to theoretical reasoning, reputation seems to aggravate the 
incentive conflict between investors and managers instead of aligning their interests. This increases the need for higher contractual restrictiveness. Furthermore, we found signs of overconfidence. Managers in times with a growing VC-pool seem to prefer higher performance-related compensation and lower fixed payments. They renounce from using their negotiation power to increase guaranteed payments over the whole funds' life. They rely more on own future performance. This does not correspond to the price adjustments we expect from rational players.

We also unveil remarkable differences between the European and the US venture capital market to those of earlier US studies conducted by Gompers and Lerner (1996) and (1999). They analysed US VC partnership agreements between 1979 and 1992. In comparison to the US, the European market seems to be different. Changing inherent incentives for fund managers with or without reputation are adjusted in the US by changing monetary incentives and in Europe by changing contractual restrictiveness. In Europe, the supply/demand situation for VC-services influences the management compensation but not the number of covenants. In the US, the contractual restrictiveness is weaker when supply of venture capital increases. When interpreting these different findings, we have to take under consideration that the European sample refers to partnership agreements which are drafted between 1996 and the end of 2001. We have no indication for the last years whether market forces on contractual arrangements also changed in the US. On the other hand, while approaching a global market standard we will maybe observe a changing European situation if we imply a mature and more professionalized US market. In the next years we can give empirical evidence.

Directions for future research are given by the analysis of dependencies between the contractual arrangements and the real net monetary performance of the VC investment and its volatility. In Fn.48 we made an initial investigation based on empirical data. However, to refer such an analysis to the results of this study it requires a corresponding dataset, which delivers performance information about the same 122 partnerships. These data are only observable over the complete period of the individual funds' life. Taking into account that the sample funds are not yet in a mature stage, appropriate data will not be available before a couple of years. 


\section{References}

[1] Aghion, P. /Bolton, P. (1992), An incomplete Contracts Approach to Financial Contracting, Review of Economic Studies, Vol. 59, pp. 473-494.

[2] Alchian, A.A./Demsetz, H. (1972), Production, Information Costs and Economic Organization, in: American Economic Review, Vol. 62, pp. 777-795.

[3] Allen, Douglas W. / Lueck, Dean (1995), Risk Preferences and the Economics of Contracts, American Economic Review (Papers and Proceedings), Vol. 85, pp. 447451.

[4] Ayres, I. / Gertner, R. (1992), Strategic Contractual Inefficiency and the optimal choice of Legal Rules, 101 Yale Law Journal, pp. 729.

[5] Barry, C. (1994), New directions in Research on Venture Capital Finance, in: Financial Management, Vol. 23.

[6] Bascha, A./ Walz, U (2002), Financing Practices in the German Venture Capital Industry: An Empirical Assessment, CFS Working Paper Nr. 2002/8.

[7] Bauer, M./ Bilo, S./ Zimmermann, H. (2001), Publicly traded Private Equity: An Empirical Investigation, Working Paper, Swiss Institute of Banking and Finance, University of St.Gallen.

[8] Beck, Thorsten / Demirgück-Kunt, Asli / Levine Ross (2002), Law and Finance: Why does legal system matter?, World Bank Policy Research Working Paper.

[9] Blake, J. et al. (1999), Private Equity Fund Structures in Europe, EVCA Europe Special Paper.

[10] Blake, J. (1999), Structuring Venture Capital Funds for Investment: The Legal Dimension, in: Bygrave/Hay/Peeters (Hrsg. 1999), The Venture Capital Handbook, pp.79-93.

[11] Brooks, J (1999), Fund-Raising and the Investor Relations, in: Bygrave/Hay/Peeters (Hrsg. 1999), The Venture Capital Handbook.

[12] Diamond, D.W. (1984), Financial Intermediation and Delegated Monitoring, in: Review of Economic Studies, Vol. 51, pp.393-414.

[13] EVCA (2001), EVCA Yearbook 2001, European Venture Capital Association.

[14] Eberwein, Curtis J. (2000), Repeated Bargaining and the Role of Impatience and Incomplete Contracting. 
[15] Feinendegen, S. / Schmidt, D./ Wahrenburg, M. (2003), Die Vertragsbeziehungen zwischen Investoren und europäischen Venture Capital-Fonds: eine empirische Untersuchung und Klassifizierung unterschiedlicher Vertragsmuster, Working Paper Goethe-Universität Frankfurt.

[16] Feinendegen, S./ Schmidt, D./ Wahrenburg, M. (2002), Die Vertragsbeziehungen zwischen Investoren und Venture Capital-Fonds: eine empirische Untersuchung des europäischen Venture Capital-Marktes, CFS Working Paper 2002/01.

[17] Fenn, G. W./Liang, N./Prowse, S. (1997), The Private Equity Market: An Overview, Boston u. a. 1997.

[18] Fenn, G.W./Liang, N./Prowse, S. (1996), The Economics of the Private Equity Market, Federal Reserve Bulletin, Washington, January 1996.

[19] Franzke, S. A. (2001), Underpricing of Venture-Backed and Non Venture-Backed IPOs: Germany's Neuer Markt, CFS Working Paper 2001/01.

[20] Glaeser, Edward L. / Shleifer, Andrei (2001), Legal Origin, Harvard University and Cambridge University, Working Paper, April 2001.

[21] Gompers, P./ Lerner, J (1999), An Analysis of Compensation in the U.S. Venture Capital Partnership, in: Journal of Financial Economics, Vol. 51, pp. 3-44.

[22] Gompers, P. / Lerner, J. (1996), The Use of Covenants: An Empirical Analysis of Venture Partnership Agreements, in: Journal of Law and Economics, Vol. 39, 1996, pp. 463-498.

[23] Gompers. P. (1995), Optimal Investment, Monitoring, and the Staging of Venture Capital. in: The Journal of Finance, Vol. 50, pp. 1461-1489.

[24] Grossmann,S. Hart, O (1983), An Analysis of the Principal Agent Problem, in: econometrica Vol 51, pp. 7-51.

[25] Gujarati, D. N. (1995), Basic Econometrics, International Edition, New York.

[26] Hart, O. /Holmström, B (1985), The theory of contracts, in Advances, in: Bewley, T.F., Economic Theory Fifth World Congress, pp.71-157.

[27] Hvide, Hans K. (2000), Pragmatic Beliefs and Overconfidence, Norwegian School of Economics and Business, Working Paper, 2000.

[28] Initiative Europe (2001), Terms and Conditions Criteria for European Private Equity Partnerships, London 2001. 
[29] Jensen, M./ Meckling, W. (1976), Theory of firm: Managerial behaviour, agency costs and ownership structure, in: Journal of Financial Economics, Vol. 3, 1976, pp. 305360.

[30] Kaplan, Steven N. / Martel, Frederic / Strömberg, Per (2002) Venture Capital Contracts around the world, unpublished preliminary draft of working paper.

[31] Kaplan, S.N./ Strömberg, P. (2001), Venture Capitalists as Principals: Contracting, Screening, and Monitoring, NBER Working Paper 8202 National Bureau of Economic Research, Cambridge.

[32] Kmenta, J. (1986), Elements of econometrics, 2d. ed, New York.

[33] Kyle, Albert S. / Wang, F. Albert (1997), Speculation Duopoly with Agreement to Disagree: Can Overconfidence Survive the Market Test?, Journal of Finance 52, December 1997, pp. 2073-2090.

[34] LaPorta, R. et al. (1997), Legal Determinants of External Finance, Journal of Finance 52, pp. 1131-1150.

[35] Malmendier, Ulrike / Tate Geoffrey (2002), Who makes Acquisitions? CEO overconfidence and the Market's Reaktion, Stanford University and Harvard University.

[36] Mirrlees, J.A. (1975), The Theory of Moral Hazard and Unobservable Behaviour, Nuffield College, Oxford, Mimeo.

[37] Owen, R.R./ Gardner, R.D. / Bunder, D.S., The Arthur Young Guide to Financing for Growth, New York 1986.

[38] Rees, R. (1985), The Theory of Principal and Agent, in: Bulletin of Economic Research, Vol. 37.

[39] Ross, S.A. (1973), The Economic Theory of Agency: The Principal's Problem, in: American Economic Review, Vol. 63, pp. 134-139.

[40] Ruhnka, J.C. /Young, J.E. (1991), Some Hypotheses about Risk in Venture Capital Investing, in: Journal of Business Venturing, Vol. 6, pp.115-133.

[41] Ruhnka, J.C. /Young, J.E. (1987), A Venture Capital Model of the Development Process for New Ventures, in: Journal of Business Venturing, Vol. 2, pp.167-184. 
[42] Sahlmann, W. (1990), The Structure and Governance of Venture-Capital Organisations, in: Journal of Financial Economics, Vol. 27, pp. 473-521.

[43] Spremann, K (1990), Asymmetrische Information, in: Zeitschrift für Betriebswirtschaft, Vol. 59, pp. 561-589.

[44] Spremann, K (1988), Reputation, Garantie, Information, in: Zeitschrift für Betriebswirtschaftslehre, Vol. 58, pp. 213-225.

[45] Stiglitz, J.E. (1974), Incentives and Risk Sharing in Sharecropping, in: Review of Economic Studies, Vol. 41, pp.219-255.

[46] Taylor, Shelly E. / Brown, J.D. (1988), Illusion and Well-Being: A Social Psychological Perspective on Mental Health, Psychological Bulletin, Vol. 103, pp. 193-210.

[47] Tradelis, Steven (1999), What's in a name? Reputation as a tradeable asset, American Economic Review, Vol. 89, pp. 548-561.

[48] Triantis, G. G. (2001), Financial Contract Design in the World of Venture Capital, John M. Olin Law \& Economics Working Paper No. 115, University of Chicago (forthcoming University of Chicago Law Review, Vol. 68, 2001), pp. 305-323.

[49] Tykvova, T. (2000), What do Economists tell us about Venture Capital Contracts, Working Paper Zentrum für Europäische Wirtschaftsforschung, Mannheim.

[50] Weinstein, Neil D. (1980), Unrealistic Optimism about Future Life Events, Journal of Personality and Social Psychology, November 1980, Vol. 39, pp. 806-820.

[51] Weitnauer, W. (2001), Rahmenbedingungen und Gestaltung von Private Equity Fonds, in: Finanzbetrieb, pp. 258-271.

[52] Yli-Renko, H./Hay, P. (1999), The Major European Venture Capital Markets, in: Bygrave, W. D./Hay, P./Peeters, J. B. (Hrsg.), The Venture Capital Handbook, pp. 2377. 


\section{Tables}

\begin{tabular}{|c|c|c|c|}
\hline & \# Covenants & $\begin{array}{r}\text { \# Covenants } \\
\text { (test for multicollinearity) } \\
\end{array}$ & $\begin{array}{r}\text { \# Covenants } \\
\text { (weighted) } \\
\end{array}$ \\
\hline Constant & $\begin{array}{r}-1097,666 \\
0,168\end{array}$ & $\begin{array}{l}1,259 \\
0,593\end{array}$ & $\begin{array}{r}-968,51 \\
0,224\end{array}$ \\
\hline $\begin{array}{l}\text { Non-Debut- } \\
\text { Fund }\end{array}$ & $\begin{array}{r}2,444^{* * *} \\
0,01\end{array}$ & $\begin{array}{r}2,658 * * * \\
0,001\end{array}$ & $\begin{array}{r}2,265 * * \\
0,013\end{array}$ \\
\hline $\begin{array}{l}\text { Time in } \\
\text { business }\end{array}$ & $\begin{array}{r}-0,1 \\
0,330\end{array}$ & & $\begin{array}{r}-0,100 \\
0,303\end{array}$ \\
\hline Fund size & $\begin{array}{r}0,00137 \\
0,390\end{array}$ & & $\begin{array}{r}0,0014 \\
0,366\end{array}$ \\
\hline $\begin{array}{l}\text { Growth of VC- } \\
\text { Pool }\end{array}$ & $\begin{array}{r}3,08 \\
0,425\end{array}$ & $\begin{array}{l}2,217 \\
0,564\end{array}$ & $\begin{array}{r}2,064 \\
0,413\end{array}$ \\
\hline $\begin{array}{l}\text { Date of } \\
\text { contracting }\end{array}$ & $\begin{array}{l}0,549 \\
0,168\end{array}$ & & $\begin{array}{l}0,485 \\
0,223\end{array}$ \\
\hline $\begin{array}{l}\text { Anglo-Saxon } \\
\text { origin of funds' } \\
\text { management }\end{array}$ & $\begin{array}{r}3,382^{* * *} \\
0,001\end{array}$ & $\begin{array}{r}3,533^{\star * *} \\
0,000\end{array}$ & $\begin{array}{r}3,075^{\star \star \star} \\
0,002\end{array}$ \\
\hline $\begin{array}{l}\text { Early stage } \\
\text { focus }\end{array}$ & $\begin{array}{r}-0,139 \\
0,860\end{array}$ & $\begin{array}{r}-0,461 \\
0,547\end{array}$ & $\begin{array}{r}-0,344 \\
0,647\end{array}$ \\
\hline $\begin{array}{l}\text { Non-Hightech } \\
\text { focus }\end{array}$ & $\begin{array}{r}-2,642 \\
0,359\end{array}$ & $\begin{array}{r}-4,156 \\
0,132\end{array}$ & $\begin{array}{r}-2,524 \\
0,362\end{array}$ \\
\hline $\mathrm{R}^{2}$ & 0,459 & 0,408 & 0,438 \\
\hline Adj. $R^{2}$ & 0,342 & 0,334 & 0,317 \\
\hline $\begin{array}{l}\text { p-value }(\mathrm{F}- \\
\text { statistic) }\end{array}$ & 0,002 & 0,000 & 0,003 \\
\hline
\end{tabular}

Notes: The table presents the results of the OLS regression; the dataset includes 46 European VC-funds. The first row presents the dependent variables: The number of included covenants (out of 14) as a measure of contractual restrictiveness. The first column presents the independent variables. "Early stage", "Non-high-tech", "Non-debut fund" and "Anglo-Saxon origin of funds' management" are dummy variables with the base variables "Late/Balanced stage", "High-tech", "Debut fund", "Non-Anglo-Saxon origin", respectively. In the second to the eight' columns the coefficients of the OLS regression analyses are presented. In italics below the $\beta$ estimates the p-value of the absolute heteroscedastic-consistent $\mathrm{t}$-statistics is presented. One, two and three asterisks indicate significance at the $10 \%, 5 \%$ and $1 \%$ level, respectively. The last three rows present the r-square, the adjusted $r$-square, and the p-value of the F-test, that the set of coefficients is equal to zero.

Testing the robustness of results we included also dummy variables for all other European countries. We find no significant coefficient for other country dummies. The coefficients of the other factors do not change.

All OLS regressions satisfy the assumptions of the classical linear regression model. The chi-square goodness of fit test confirms the normality of the disturbance terms. The null hypotheses that the disturbances came from the normality probability distribution can not be rejected (chi-square $=0$; $p$-value $=1$ ).

It is conceivable that some econometric variables affect the contractual design and are, in turn, affected by it. It is likely that investors' decision concerning their investment amount is influenced by the quality of contractual design. We tested for simultaneity between compensations and fund sizes by applying the Hausman Specification Test. The hypothesis of simultaneity between \# of covenants and fund size is rejected (t-value of $\left.\hat{\varepsilon_{i}}=0,492\right)$. [Gujarati, 1995, pp.670 ff.]

Table 9: Regression Analyses Covenants 


\begin{tabular}{|c|c|c|c|c|c|c|c|c|c|}
\hline & \begin{tabular}{|l|} 
Panel 1 \\
\end{tabular} & & & & Panel 2 & & Panel 3 & & Panel 4 \\
\hline & \begin{tabular}{|r} 
NPV \\
Management \\
Fee (lifetime10 \\
years \\
standardized)
\end{tabular} & $\begin{array}{r}\text { NPV } \\
\text { Manageme } \\
\text { nt Fee } \\
\text { (lifetime10 } \\
\text { years } \\
\text { standardized) } \\
\text { (test for } \\
\text { multicollineari } \\
\text { ty) }\end{array}$ & $\begin{array}{r}\text { NPV } \\
\text { Management } \\
\text { Fee (lifetime10 } \\
\text { years } \\
\text { standardized) } \\
\text { (test for } \\
\text { multicollinearity) }\end{array}$ & $\begin{array}{r}\text { NPV } \\
\text { Management } \\
\text { Fee (lifetime10 } \\
\text { years } \\
\text { standardized) } \\
\text { (test for } \\
\text { multicolinearity) }\end{array}$ & $\begin{array}{r}\text { Sensitivity } \\
\text { (carry/ } \\
\text { NPV Mgt } \\
\text { Fee) }\end{array}$ & $\begin{array}{r}\text { Sensitivity } \\
\text { (test for } \\
\text { multicol- } \\
\text { linearity) }\end{array}$ & $\begin{array}{r}\text { Sensitivity } \\
\text { II (value of } \\
\text { carry } \\
\text { option/ } \\
\text { NPV Mgt } \\
\text { Fee) }\end{array}$ & $\begin{array}{r}\text { Sensitivity } \\
\text { II (value of } \\
\text { carry } \\
\text { option/ } \\
\text { NPV Mgt } \\
\text { Fee) } \\
\text { (t. for } \\
\text { mult.coll.) }\end{array}$ & $\begin{array}{r}\text { Total } \\
\text { Compen- } \\
\text { sation } \\
\text { (NPV } \\
\text { Manage- } \\
\text { ment } \\
\text { Fee+Op- } \\
\text { tion Value } \\
\text { Carry) } \\
\end{array}$ \\
\hline Constant & $\begin{array}{r}-2,9 \\
0,565\end{array}$ & $\begin{array}{r}0,185^{\star * *} \\
0,00\end{array}$ & $\begin{array}{r}0,182^{* * *} \\
0,00\end{array}$ & $\begin{array}{r}-6,727 \\
0,155\end{array}$ & $\begin{array}{l}42,50 \\
0,693\end{array}$ & $\begin{array}{r}1,03 \\
0,000\end{array}$ & $\begin{array}{l}32,35 \\
0,694\end{array}$ & $\begin{array}{l}0,784 \\
0,000\end{array}$ & $\begin{array}{r}-2,295 \\
0,719\end{array}$ \\
\hline $\begin{array}{l}\text { Non-Debut- } \\
\text { Fund }\end{array}$ & $\begin{array}{r}-0,0043 \\
0,498\end{array}$ & $\begin{array}{r}-0,005 \\
0,382\end{array}$ & & $\begin{array}{r}-0,00334 \\
0,536\end{array}$ & $\begin{array}{r}0,0332 \\
0,809\end{array}$ & $\begin{array}{r}-0,001 \\
0,992\end{array}$ & $\begin{array}{r}0,0252 \\
0,809\end{array}$ & $\begin{array}{r}-0,0008 \\
0,992\end{array}$ & $\begin{array}{r}-0,0003 \\
0,974\end{array}$ \\
\hline $\begin{array}{l}\text { Time in } \\
\text { business }\end{array}$ & $\begin{array}{r}0,0002 \\
0,747\end{array}$ & & $\begin{array}{r}0,00018 \\
0,725\end{array}$ & & $\begin{array}{r}-0,0089 \\
0,518\end{array}$ & & $\begin{array}{r}-0,00681 \\
0,518\end{array}$ & & $\begin{array}{r}-0,0001 \\
0,900\end{array}$ \\
\hline Fund size & $\begin{array}{r}-0,000012 \\
0,321\end{array}$ & & & & $\begin{array}{r}0,0001 \\
0,693\end{array}$ & & $\begin{array}{r}0,000079 \\
0,694\end{array}$ & & $\begin{array}{r}-0,000012 \\
0,480\end{array}$ \\
\hline $\begin{array}{l}\text { Growth of } \\
\text { VC-Pool }\end{array}$ & $\begin{array}{r}-0,0598^{\star * *} \\
0,008\end{array}$ & $\begin{array}{r}-0,0635^{\star \star *} \\
0,002\end{array}$ & $\begin{array}{r}-0,068^{\star \star *} \\
0,003\end{array}$ & & $\begin{array}{r}0,819^{*} \\
0,086\end{array}$ & $\begin{array}{r}0,85^{\star *} \\
0,049\end{array}$ & $\begin{array}{r}0,624^{*} \\
0,086\end{array}$ & $\begin{array}{r}0,647^{* *} \\
0,049\end{array}$ & $\begin{array}{r}-0,0502^{*} \\
0,076\end{array}$ \\
\hline $\begin{array}{l}\text { Date of } \\
\text { contracting }\end{array}$ & $\begin{array}{r}0,0015 \\
0,540\end{array}$ & & & $\begin{array}{r}0,00344 \\
0,146\end{array}$ & $\begin{array}{r}-0,0202 \\
0,7\end{array}$ & & $\begin{array}{r}-0,0158 \\
0,701\end{array}$ & & $\begin{array}{r}0,0013 \\
0,681\end{array}$ \\
\hline $\begin{array}{l}\text { Anglo- } \\
\text { Saxon } \\
\text { origin of } \\
\text { funds' } \\
\text { manage- } \\
\text { ment }\end{array}$ & $\begin{array}{r}-0,0092 \\
0,137\end{array}$ & $\begin{array}{r}-0,009 \\
0,142\end{array}$ & $\begin{array}{r}-0,0085 \\
0,156\end{array}$ & $\begin{array}{r}-0,0098 \\
0,108\end{array}$ & $\begin{array}{r}0,0538 \\
0,684\end{array}$ & $\begin{array}{l}0,044 \\
0,721\end{array}$ & $\begin{array}{l}0,040 \\
0,685\end{array}$ & $\begin{array}{l}0,034 \\
0,722\end{array}$ & $\begin{array}{r}-0,004 \\
0,575\end{array}$ \\
\hline $\begin{array}{l}\text { Early stage } \\
\text { focus }\end{array}$ & $\begin{array}{r}0,0137^{\star *} \\
0,014\end{array}$ & $\begin{array}{r}0,0136^{* * *} \\
0,010\end{array}$ & $\begin{array}{r}0,0134^{* *} \\
0,0137\end{array}$ & $\begin{array}{r}0,0126^{\star *} \\
0,022\end{array}$ & $\begin{array}{c}-0,24^{*} \\
0,044\end{array}$ & $\begin{array}{r}-0,230^{\star *} \\
0,041\end{array}$ & $\begin{array}{r}-0,183^{\star *} \\
0,044\end{array}$ & $\begin{array}{r}-0,176^{* *} \\
0,042\end{array}$ & $\begin{array}{r}0,0138^{\star *} \\
0,05\end{array}$ \\
\hline $\begin{array}{l}\text { Non- } \\
\text { Hightech } \\
\text { focus }\end{array}$ & $\begin{array}{r}-0,0294^{* *} \\
0,014\end{array}$ & $\begin{array}{r}-0,0297^{\star * *} \\
0,008\end{array}$ & $\begin{array}{r}-0,0281^{* *} \\
0,0135\end{array}$ & $\begin{array}{r}-0,0227^{\star \star} \\
0,05\end{array}$ & $\begin{array}{l}0,371 \\
0,140\end{array}$ & $\begin{array}{r}0,36 \\
0,137\end{array}$ & $\begin{array}{l}0,283 \\
0,141\end{array}$ & $\begin{array}{l}0,274 \\
0,133\end{array}$ & $\begin{array}{r}-0,0263^{*} \\
0,079\end{array}$ \\
\hline $\mathrm{R}^{2}$ & 0,183 & 0,182 & 0,173 & 0,127 & 0,086 & 0,086 & 0,087 & 0,086 & 0,103 \\
\hline Adj. $R^{2}$ & 0,122 & 0,146 & 0,135 & 0,088 & 0,02 & 0,045 & 0,018 & 0,046 & 0,035 \\
\hline $\begin{array}{l}\text { p-value (F- } \\
\text { statistic) }\end{array}$ & 0,004 & 0,000 & 0,000 & 0,008 & 0,27 & 0,06 & 0,27 & 0,067 & 0,160 \\
\hline
\end{tabular}

Notes: The table presents the results of the OLS regression. The number of included observation varies and is shown in table 4, 5, and 6. The first interest to NPV of management fee/panel 2), the revised measure of compensation sensitivity (the ratio of the carries' option value to the NPV of Mgt Fee/ panel 3) and the total compensation (NPV of Management Fee + option value carry/panel 4).

Testing the robustness of results we included also dummy variables for all other European countries. Results do not change. We find no significant coefficient for other country dummies.

The hypothesis of simultaneity between NPV of Mgt Fee and fund size is rejected (t-value of $\hat{\varepsilon}_{i}=-0,873$ ), of simultaneity between sensitivity and fund size is rejected (t-value of $\hat{\varepsilon}_{i}=0,727$ ), and of simultaneity between the revised sensitivity and fund size is rejected (t-value of $\hat{\varepsilon}_{i}=0,725$ ). For more details see notes of table 9 .

Table 10: Regression analysis: compensation terms I 


\begin{tabular}{|c|c|c|c|c|}
\hline & Panel 1 & Panel 2 & & \\
\hline & $\begin{array}{r}\text { Capital Contribution (Logit) } \\
\text { Reference Group } \\
\text { Contribution=1 }\end{array}$ & $\begin{array}{r}\text { Hurdle Rate } \\
\text { (OLS) }\end{array}$ & $\begin{array}{r}\begin{array}{r}\text { Hurdle Rate } \\
\text { (Logit) }\end{array} \\
\text { Reference group: Hurdle } \\
\text { Rate }=1 \\
\end{array}$ & $\begin{array}{r}\begin{array}{r}\text { Hurdle Rate } \\
\text { (Logit) }\end{array} \\
\text { Reference group: Hurdle } \\
\text { Rate }=1 \\
\end{array}$ \\
\hline Constant & $\begin{array}{r}137,33 \\
0,84\end{array}$ & $\begin{array}{r}-3,62 \\
0,59\end{array}$ & $\begin{array}{r}-285,2 \\
0,301\end{array}$ & $\begin{array}{r}1,485^{\star *} \\
0,023\end{array}$ \\
\hline Non-Debut-Fund & $\begin{array}{r}1,95^{\star \star}(7,05) \\
0,039\end{array}$ & $\begin{array}{r}-0,0003 \\
0,972\end{array}$ & $\begin{array}{r}-0,154(0,859) \\
0,750\end{array}$ & $\begin{array}{r}-0,476(0,621) \\
0,215\end{array}$ \\
\hline Time in business & $\begin{array}{r}-0,073(0,996) \\
0,444\end{array}$ & $\begin{array}{r}0,00157^{*} \\
0,073\end{array}$ & $\begin{array}{r}-0,078(0,924) \\
0,119\end{array}$ & \\
\hline Fund size & $\begin{array}{r}0,00307(0,997) \\
0,448\end{array}$ & $\begin{array}{r}0,0000076 \\
0,645\end{array}$ & $\begin{array}{r}0,0002(1,0) \\
0,834\end{array}$ & \\
\hline Growth of VC-Pool & $\begin{array}{r}-2,58(0,075) \\
0,463\end{array}$ & $\begin{aligned}-0,052^{*} \\
0,082\end{aligned}$ & $\begin{array}{r}-2,639^{*}(0,07) \\
0,1\end{array}$ & $\begin{array}{r}-2,9^{* *}(0,054) \\
0,05\end{array}$ \\
\hline Date of contracting & $\begin{array}{r}-0,06(0,93) \\
0,84\end{array}$ & $\begin{array}{r}0,0018 \\
0,584\end{array}$ & $\begin{array}{r}0,193(1,21) \\
0,29\end{array}$ & \\
\hline $\begin{array}{l}\text { Anglo-Saxon origin of funds' } \\
\text { management }\end{array}$ & $\begin{array}{r}0,823(2,27) \\
0,373\end{array}$ & $\begin{array}{r}0,0012 \\
0,878\end{array}$ & $\begin{array}{r}-0,175(0,839) \\
0,69\end{array}$ & $\begin{array}{r}-0,0637(0,938) \\
0,882\end{array}$ \\
\hline Early stage focus & $\begin{array}{r}-0,028(0,975) \\
0,96\end{array}$ & $\begin{array}{r}-0,009 \\
0,18\end{array}$ & $\begin{array}{r}-0,352(0,70) \\
0,383\end{array}$ & $\begin{array}{r}-0,332(0,725) \\
0,402\end{array}$ \\
\hline Non-Hightech focus & $\begin{array}{r}19,58(321657276) \\
0\end{array}$ & $\begin{array}{r}-0,0116 \\
0,454\end{array}$ & $\begin{array}{r}0,881(2,41) \\
0,346\end{array}$ & $\begin{array}{r}0,545(1,725) \\
0,541\end{array}$ \\
\hline$\overline{\mathrm{R}^{2}}$ & & 0,097 & & \\
\hline Adj. $R^{2}$ & & 0,031 & & \\
\hline p-value (F-statistic) & & 0,18 & & \\
\hline$\underset{(\mathrm{p} \text {-value })}{\chi^{2} \text {-statistics }}$ & $\begin{array}{r}8,03 \\
(0,429)\end{array}$ & & $\begin{array}{r}11,88 \\
(0,158)\end{array}$ & $\begin{array}{r}7,1 \\
(0,213)\end{array}$ \\
\hline \multicolumn{5}{|c|}{$\begin{array}{l}\text { Notes: The table presents the results of the OLS regression and Logit analyses. The number of included observation varies and is shown in } \\
\text { table } 5 \text { and } 7 \text {. The first row presents the dependent variables: obligated capital contribution by the venture capitalist and hurdle rate. The first, } \\
\text { the third, and the fourth column present the results of the Logit-Analyses with funds obligating a capital contribution or conceding a hurdle } \\
\text { rate coded as } 1 \text { (reference group) and those not obligating a contribution or not conceding a hurdle rate coded as } 0 \text {. In the brackets next to the } \\
\beta \text { estimates the odd-ratios are presented. In Italics the level of significances according to the Wald-test-statistics is given. The last four } \\
\text { rows present the r-square, the adjusted r-square, the p-value of the F-test, that the set of coefficients is equal to zero, and the chi-square } \\
\text { statistic (model fitting). For more details see notes of table } 3 \text {. }\end{array}$} \\
\hline \multicolumn{5}{|c|}{$\begin{array}{l}\text { Testing the robustness of results we included also dummy variables for all other European countries. Results do not change. We find no } \\
\text { significant coefficient for other country dummies. }\end{array}$} \\
\hline
\end{tabular}

Table 11: Regression Analysis: compensation terms II 


\section{Appendix - Description of the analysed covenants}

In this section we give a quality description of the analysed covenants of the three subclasses. The following four covenants correspond to class one:

The first covenant restricts the size of investment in one firm. Due to the carried interest, which is paid after the investors have received at least 100 per cent of their invested capital, the VC contract can be seen as a call option. This fact suggests an inherent agency problem. According to the Black-Scholes model the value of a call option increases with higher risk. Value maximation of the call option owned by the venture capitalists implies therefore an attitude to increase risk. The venture capitalist does not participate in the monetary loss in the case of a negative return. To invest a higher amount in one portfolio company increases risk at the expense of diversification. Therefore, this covenant restricts the received risk. Moreover this covenant ensures the attempt of the venture capitalist to salvage an investment in a poorly performing company by doing several follow-on investments. ${ }^{52}$

The second covenant restricts the use of debt. As mentioned above the venture capitalist is an option holder and has incentives to increase the variance of their portfolios' returns. Leveraging the fund will increase the received risk. This increases the value of the venture capitalists' call option at the investors' expense. The existence of a covenant that restricts the venture capitalists' ability to borrow capital or to guarantee the debt of their portfolio companies reduces the venture capitalists' opportunities of increasing his private benefit ${ }^{53}$

Restrictions on co-investment with the same venture organizations' earlier or later funds are given by the third covenant. The limited partnership as the organisational form allows the investment managers to manage several funds, which are formed some years apart. In contrast to a single investor, who is only interested in the performance of the fund he has actually invested in, the managing partners have to care about all the managed funds. The utility function of the managing partners is dependent on the performance and the private benefit received by all funds. Opportunistic behaviour is likely to be the result. Co-investment with earlier funds may often be the solution to salvage bad performing portfolio companies from earlier limited partnerships. New capital infusions will be used to improve the status or

\footnotetext{
${ }^{52}$ Sahlmann (1990), pp.496 und Gompers/Lerner (1996), pp. 480 und Harris, M./ Raviv, A. (1979), pp. 231 f.

${ }^{53}$ Gompers / Lerner (1996), pp. 480
} 
performance of earlier funds. The capital, which originally concerns to a later fund is not invested optimally for the investor's purpose, but helps to increase the venture capitalists' private benefit. Covenants on co-investment with earlier funds exist on different extent. Some partnerships are completely restricted to co-invest, some others need the approval of the fund's advisory board or the majority of the limited partners. ${ }^{54}$

Restrictions on reinvestment of capital gains should reduce private benefit as well. This kind of covenant is needed, because tapered compensation terms give the managing partners incentives to maximize the assets under investment. After the commitment period, management fees are often paid on basis of assets under management. Furthermore, the likelihood of higher carried interest payments is maximized if an increasing amount of capital is at the venture capitalists disposal for investment. Moreover, reinvestment of capital gains at advanced funds' life increases the probability of extending the funds life. Recent investments are not mature enough to liquidate. The managing partners would continue to generate fees. Distributing capital gains would lower the compensation, which is paid to the venture capitalist. Therefore, the incentives of managing partners to reinvest capital gains are high, but not always optimal for the investors' purpose. The investor would have more chances to maximize his utility, if he could make the decision of reinvestment by himself. He would be even free to invest in a better performing fund. ${ }^{55}$

The following covenants correspond to covenant class two and restrict the activities of the managing directors:

The fifth covenant settles the possibility of co-investing by managing partners in portfolio companies. Direct investment in a portfolio company is restricted or limited. Co-investment in certain portfolio companies would dilute the incentive that is given by the carried interest to optimise the entire portfolio. The carried interest can be seen as an indirect participation on the whole portfolio. Single selected investments in certain portfolio companies would intensify the managing partners' effort to increase the return of these companies. A portfolio optimisation is not guaranteed. ${ }^{56}$

\footnotetext{
${ }^{54}$ Gompers / Lerner (1996), pp. 481

${ }^{55}$ Gompers, P. / Lerner, J. (1996), pp. 481

${ }^{56}$ Gompers/Lerner (1996), pp.481 f.
} 
Covenant number six restricts or limits the managing partners' ability of investing in non portfolio companies, which are acting in the same or similar business fields that correspond to the funds investment area. The managing partners are restricted to do own investments in high quality companies, instead investing funds' capital. Their monetary return should exclusively be generated by participating the portfolio return. This increases the incentive to take all potentially highly rewarded emerging companies, the managing partners have the opportunity to invest in, into the portfolio.

Capital contribution of the managing directors was one of the mentioned solutions of agency problems. Restrictions on selling the managing partners' partnership shares or interests maintain the incentives that are given by a capital contribution for the funds' whole life. Covenant number seven limits the sale of partnership shares. Contractual regulations differ. Sometimes, partnership agreements restrict the managing partners completely to participate the venture fund. Some other agreements prescribe a participating share of a determined amount, but do not restrict a later sale of those shares. Long lasting real incentives are given, if the participation is prescribed and the sale of partnership shares is restricted. ${ }^{57}$

Covenant number eight restricts new fund raising by the managing partners over the managing period. They should engage completely in managing one fund. A new fund raising would reduce the venture capitalists' attention on managing the former fund. The overall management fees paid by the limited partners of both funds, however, would increase. Usually the managing partners are restricted to raise new funds until a certain amount, mostly 75 per cent, of committed capital is invested. ${ }^{58}$

The next covenant restricts outside actions done by the managing partners. Other actions than managing the venture fund are likely to reduce the effort given to the portfolio-management. Especially within the commitment period, where the due diligence of potential portfolio companies takes much time, all attention should be spend for managing the fund. According to that need this kind of covenant refers often only to a period of time until a certain amount

\footnotetext{
${ }^{57}$ Gompers/Lerner (1996), pp. 482 ; Section 6.3 analyses the sample partnerships about the interaction of covenant number seven and the capital contribution that has to be donated by the investment managers.

${ }^{58}$ Gompers / Lerner (1996), pp. 482
} 
of committed capital is invested. The analysis of the partnership agreements shows, that in most cases only other investment activities or consulting activities are restricted. That is a weak form of this covenant, but, however, it restricts opportunistic behaviour of the managing partners. It prevents conflicts, which arise by investing capital from different sources and consulting different venture funds.

Covenant number ten restricts the addition of new managing partners. An extremely important factor within the due diligence process is the assessment of managing partners' former performance. The quality of the management is a soft factor, which cannot be measured on a quantitative basis. ${ }^{59}$ The later addition of new managing partners would take the investors possibility of judging the involved managing partners in advance. Less talented and competent managing partners could join the limited partnership and would dilute the overall managing performance. The originally involved venture capitalists may reduce their efforts for the funds' management and may increase private benefits by concentrating on other actions. $^{60}$

The last four covenants correspond to the covenant class three and restrict the type of investment.

As mentioned above, the assessment of the managing partners' competence and their extensive reputation in that kind of business are often decisive to make an actual investment. The eleventh covenant restricts the managing partners' ability to invest funds' capital in other venture funds. By doing so they would give investment decisions out of their hands. The managing partners would earn the same high compensation and would have less expenditure. These kinds of restrictions are particularly important for fund of fund investment companies to carry out wise investment decisions. To achieve the aspired return-risk profile, they have to relay on the pronounced investment procedure of the funds. Therefore, covenants, which adjust this on a contractual basis, are important for their portfolio management. ${ }^{61}$

\footnotetext{
${ }^{59}$ Zemke (1995), pp. $136 \mathrm{f}$.

${ }^{60}$ Gompers / Lerner (1996), pp. 482 f. and Zemke (1995), pp. 137 f.

${ }^{61}$ Gompers/Lerner (1996), pp. 483 and Ruhnka/Young (1991), pp. 116 ff. and Weitnauer (2001), pp. 269.
} 
Another covenant restricts investments in public traded securities. These kinds of investments do not meet the requirements which are made on a VC fund. Venture capital investment is a more complicated investment process. The compensation that is received by the VC investment manager is much higher. Expectations on return on capital are also higher. Investors expect the venture capitalist to concentrate on their core business.

The thirteen's covenant restricts also the type of investment. This covenant restricts the investment in other asset classes like e.g., derivative instruments or real estate. The use of derivatives and similar products would increase the risk associated with the capital investment. As mentioned before, rising risk increases the value of the venture capitalists' compensation. He would generate private benefit. Moreover, this kind of covenant often restricts investments in asset classes where the managing partners have little expertise. The managers' purpose of investing in other kinds of assets is to gain experience and reputation. This non-monetary private benefit would help the venture capitalists to expand their investment skills and to attract potential future investors. Actual investors would not gain advantages from that kind of investment experiments. ${ }^{62}$

Finally, we analysed a covenant that restricts the investment in companies which are actually controlled by the managing partners. Moreover, it restricts investment, if the managing partners are already invested in that company for their own account. The venture capitalists could increase their private benefit by investing funds' capital in companies where they hold a monetary participation. This could lead to opportunistic behaviour of the managing partners, because an investment in those companies will not always be the optimal choice.

\footnotetext{
${ }^{62}$ Gompers/Lerner (1996), pp. 483 f.
} 


\section{CFS Working Paper Series:}

\begin{tabular}{|c|c|c|}
\hline No. & Author(s) & Title \\
\hline $2003 / 05$ & Volker Wieland & $\begin{array}{l}\text { Monetary Policy and Uncertainty about the } \\
\text { Natural Unemployment Rate }\end{array}$ \\
\hline 2003/06 & $\begin{array}{l}\text { Andrew Levin } \\
\text { Volker Wieland } \\
\text { John C. Williams }\end{array}$ & $\begin{array}{l}\text { The Performance of Forecast-Based Monetary } \\
\text { Policy Rules under Model Uncertainty }\end{array}$ \\
\hline 2003/07 & $\begin{array}{l}\text { Günter Coenen } \\
\text { Andrew Levin } \\
\text { Volker Wieland }\end{array}$ & $\begin{array}{l}\text { Data Uncertainty and the Role of Money as an } \\
\text { Information Variable for Monetary Policy }\end{array}$ \\
\hline 2003/08 & $\begin{array}{l}\text { Günter Coenen } \\
\text { Volker Wieland }\end{array}$ & $\begin{array}{l}\text { A Small Estimated Euro Area Model with } \\
\text { Rational Expectations and Nominal Rigidities }\end{array}$ \\
\hline 2003/09 & $\begin{array}{l}\text { Günter Coenen } \\
\text { Volker Wieland }\end{array}$ & $\begin{array}{l}\text { The Zero-Interest-Rate and the Role of the } \\
\text { Exchange Rate for Monetary Policy in Japan }\end{array}$ \\
\hline $2003 / 10$ & $\begin{array}{l}\text { Stefan Reitz } \\
\text { Frank Westerhoff }\end{array}$ & $\begin{array}{l}\text { Nonlinearities and Cyclical Behavior: } \\
\text { The Role of Chartists and Fundamentalists }\end{array}$ \\
\hline 2003/11 & $\begin{array}{l}\text { Stefan Reitz } \\
\text { Ralf Ahrens }\end{array}$ & $\begin{array}{l}\text { Heterogeneous Expectations in the Foreign } \\
\text { Exchange Market Evidence from the Daily } \\
\text { Dollar/DM Exchange Rate }\end{array}$ \\
\hline $2003 / 12$ & Klaus Adam & $\begin{array}{l}\text { Optimal Monetary Policy with } \\
\text { Imperfect Common Knowledge }\end{array}$ \\
\hline
\end{tabular}

2003/13 Günter Coenen

Athanasios Orphanides

Volker Wieland

2003/14Ｒaimond Maurer

Institutional Investors in Germany: Insurance

Companies and Investment Funds

2003/15

Daniel Schmidt
Mark Wahrenburg

Contractual Relations between European VCFunds and Investors: The Impact of Reputation and Bargaining Power on Contractual Design

Copies of working papers are available at the Center for Financial Studies or can be downloaded (http://www.ifk-cfs.de). 